This item was submitted to Loughborough's Research Repository by the author.

Items in Figshare are protected by copyright, with all rights reserved, unless otherwise indicated.

\title{
Infrastructure provision, gender, and poverty in Indian slums
}

PLEASE CITE THE PUBLISHED VERSION

http://dx.doi.org/10.1016/j.worlddev.2014.09.014

\section{PUBLISHER}

(c) Elsevier

\section{VERSION}

SMUR (Submitted Manuscript Under Review)

\section{PUBLISHER STATEMENT}

This work is made available according to the conditions of the Creative Commons Attribution-NonCommercialNoDerivatives 4.0 International (CC BY-NC-ND 4.0) licence. Full details of this licence are available at: https://creativecommons.org/licenses/by-nc-nd/4.0/

\section{LICENCE}

CC BY-NC-ND 4.0

\section{REPOSITORY RECORD}

Parikh, Priti, Kun Fu, Himanshu Parikh, Allan McRobie, and Gerard George. 2019. "Infrastructure Provision, Gender, and Poverty in Indian Slums". figshare. https://hdl.handle.net/2134/23033. 
Infrastructure Provision, Gender and Poverty in Indian slums

*Priti Parikh, Kun Fu, Himanshu Parikh, Allan McRobie, Gerard George

*Priti Parikh, University College London,

Email: priti.parikh@ucl.ac.uk

Kun Fu, Imperial College London,

Email: k.fu@imperial.ac.uk

Himanshu Parikh

Himanshu Parikh Consulting Engineers,

Email: hhp@dataone.in

Allan McRobie

Cambridge University Engineering Department,

Email: fam@eng.cam.ac.uk

Gerard George, Imperial College London,

Email: g.george@imperial.ac.uk

\section{Cite this paper as:}

Parikh, P. Fu, K., Parikh, H. McRobie, A., George, G. 2015. Infrastructure Provision, Gender and Poverty in Indian Slums, World Development, 66: 468-486. 


\title{
Infrastructure Provision, Gender and Poverty in Indian slums
}

\begin{abstract}
We examine the relationship between infrastructure provision and poverty alleviation by analysing 500 interviews conducted in serviced and non-serviced slums in India. Using a mixed-method approach of qualitative analysis and regression modelling, we find that infrastructure was associated with a $66 \%$ increase in education among females. Service provision increased literacy by $62 \%$, enhanced income by $36 \%$, and reduced health costs by $26 \%$. Evidence suggests that a gender-sensitive consideration of infrastructure is necessary and that a 'one size fits all' approach will not suffice. We provide evidence that infrastructure investment is critical for well-being of slum dwellers and women in particular.
\end{abstract}

\section{KEYWORDS}

Slums, Asia, India, infrastructure, gender, poverty, health, literacy

\section{ACKNOWLEDGEMENTS}

Priti Parikh would like to thank Newnham College, Cambridge and the UK Engineering and Physical Sciences Research Council for funding her doctorate which forms the basis of this paper. This study would have not been possible without the support of the slum dwellers who patiently responded to the questionnaires. Gerry George gratefully acknowledges the support of the Professorial Fellowship of the UK's Economic and Social Research Council (RES051-27-0321). 


\section{INTRODUCTION}

With high rates of population growth and urbanisation, the provision of infrastructure in urban centres of developing countries is of utmost importance. Infrastructure in the form of water and sanitation is essential for achieving the Millennium Development Goals (Fay et al, 2005. There is evidence to support the direct link between infrastructure investment and national economic growth (Esfahani \& Ramirez, 2003). Across countries, a 1\% increase in the stock of infrastructure typically corresponds with a $1 \%$ increase in GDP (World Bank (WB), 1994). Infrastructure can deliver major benefits in economic growth, poverty alleviation, and environmental sustainability (Parikh, Parikh \& McRobie, 2012). Whilst global development agencies recognise the importance of safe water and environmental sanitation, reports show that the world is likely to miss the Millennium Development Goal 7 of halving the proportion of the population without access to sustainable sanitation by $10 \%$ of the intended target population (e.g., United Nations (UN), 2011). It is estimated that the global population will increase by 2 billion by 2030, with most of the increase occurring in the developing world, and predominantly in urban settlements (Bhattacharya, Romani \& Stern, 2012).

In India, the recent census (Government of India (GOI), 2010) reports a slum population of 93 million. Slums are characterised by illegal land tenure, inadequate infrastructure, poor quality housing stock and poor neighbourhood conditions (Gulyani \& Talukdar, 2008). Globally, the infrastructure gap is increasing as slum population's rise and living conditions in slums deteriorate (UN, 2011). The low income settlements are denser and more challenging to serve because of issues related to land tenure, ownership, resources, access and high densities (WB, 2004).

Inequity is not just restricted to the quality of access to services based on income. Within low income communities, women face greater barriers for economic and social mobility (Prabhu, 2010; WB, 2006). Access to institutional support, infrastructure services 
and financial support is often inequitable and restricted for women in Indian settlements (UNDP, 2006; WB, 2006). For example, there is institutionalised gender bias against the education of female children in India (Dercon \& Singh, 2013). Women bear the brunt of inadequate infrastructure provision as they have to spend time on water collection, waste disposal and collection of fuel wood for energy provision (Floro \& Swain, 2013; Parikh, Chaturvedi \& George, 2012; UNDP, 2006). In Indian slums, girls spend time for water collection in lieu of attending school, resulting in gender imbalances in education levels. Consequently, the infrastructure provision gap and its negative effects on aspiration and upward socioeconomic mobility are likely becoming more pronounced.

The notion that economic growth brings about reductions in both mortality and fertility rates has been advocated by many governments and donor agencies, and yet it was the public health movement - rather than economic growth - which was the key driver for the health improvements seen in $19^{\text {th }}$ century London (Szreter, 2005). Research in India (Joshi, 2002; Sheshagiri, 2006) and eastern Uganda (UNDP, 2006) found that women spend, on average, two hours per day for water collection and disposal. If this time is saved via infrastructure provision, it would give women a greater capacity to participate in society, children the opportunity to attend school, and would meet the criterion of fair distribution of time and resources (Moser, 1998; UNDP, 2006). We posit that given that women face greater adversity in absence of adequate infrastructure it is likely that they will reap greater benefits from the provision of services.

The capabilities and functionings approach propagated by Sen (1999) examines functional capabilities which could be in the form of, say, freedom to participate in an activity or society due to removal of barriers. Inadequate infrastructure provision potentially has a detrimental effect on well-being through time and resource loss thus infrastructure provision could improve the functioning of slum dwellers through freeing up their time and resources thereby resulting in improved productivity. 
Despite the general awareness of this infrastructure provision gap, there is limited availability of data in slums due to the combined difficulties of collecting data in a resourceconstrained setting, limited evidence gathering by governments and the informality of community structures that need to be leveraged during the data gathering process. This study collected primary data conducting 500 household interviews in five Indian slum settlements. Through the use of rigorous data collection and a mixed-method approach, we document the positive changes in socio-economic indicators of health, education, income and housing after the provision of integrated household infrastructure (water, sanitation, drainage, solid waste management, roads and electricity) with emphasis on direct benefits for women and girls.

\section{LITERATURE REVIEW}

Using World Development Report figures for ninety-nine developing countries, Caldwell (1986) found no direct link between income and health. In particular, the better levels of health in China, Sri Lanka, Costa Rica and Kerala were attributed to factors such as equity and public health provision. Numerous studies (for example Calderón \& Servén, 2004; Straub, 2008) have shown the impact of infrastructure on overall human development. Policy changes which enhance the provision of infrastructure - particularly water and sanitation - for the poor in developing countries have a positive impact on health, education, income and welfare (Calderón \& Servén 2004; UNDP 2006; WB 2004). There is a direct effect of infrastructure capital in nations which manifests in the form of a simple productivity effect potentially leading to growth (Straub, 2008). Infrastructure further enhances labour productivity through time saved and reduction in time wastage (Straub, 2008).

Slum communities in India that have limited access to basic services incur significant costs and losses as inferior environmental conditions result in poor health thereby reducing productivity and potential asset base (Parikh,Parikh \& McRobie, 2012). Infrastructure such as energy can enable slum dwellers or disenfranchised rural communities to shift from survival mode to a higher quality of life (Parikh, Chaturvedi \& George, 2012; Schillebeeckx et al., 
2012). Sen (1999) proposes a "Capabilities Approach," which emphasizes access and development of localized capabilities, would highlight the causes of deprivation more comprehensively than an income-based assessment. Moser (1998) argues that incomeconsumption is not always a good measure of poverty, and that vulnerability better captures the change process of people moving in and out of poverty. We apply Sen's capabilities lens to the provision of infrastructure and its role in potentially improving productivity and living conditions in slums.

'The Challenge of Slums' (UN-HABITAT, 2003) was the first global assessment of slums presenting estimates of slum populations and identifying the main slum policies and frameworks. The assessment acknowledges that in-situ slum upgrading has significant advantages in terms of affordability compared to relocation and can be achieved with minimal disturbance to the social and economic life of communities and lead to visible results on the ground. Holistic, well-being and multidimensional approaches have been used to examine slum living conditions in Brazil (Feler \& Henderson, 2011), India (Lall et al., 2008) and Nairobi (Gulyani \& Talukdar, 2008). Uni-sectoral studies are prevalent with discussion on health and education in slums (Asthana, 1995; Butal et al., 2010). This study aims to build on existing studies and carry out a holistic multi-sectoral assessment of the impact of infrastructure.

In India, studies carried out by academic institutions such as the Centre for Environment Planning and Technology (CEPT) and charities such as the Self Employed Women's Association (SEWA) and SAATH have investigated the impact of physical infrastructure on health, education and incomes (CEPT, 2004; Joshi, 2002; SEWA, 2002) but they lack statistical rigour and technical expertise. In 2004, CEPT (supported by World Bank, SAATH and SEWA) studied a sample of 25 slums in the city of Ahmedabad in India via focus group discussions and household surveys which included 17 slums serviced through the Slum Networking Project (SNP). SEWA and the United States Agency for International 
Development (USAID) also conducted household interviews in 297 houses in three settlements in Ahmedabad (SEWA, 2002). The study looked at two settlements where services have been implemented and one adjoining settlement which is non-serviced. SEWA (2002) reported the positive impact of infrastructure but the study is less detailed than the CEPT study. In 1997, SAATH conducted a socio-economic survey in the settlement of Pravinnagar in Ahmedabad city to collect baseline and end line data (Joshi, 2002). Positive findings from the study include improvement in pre-and post-natal care and an increase in school enrolment (Joshi, 2002). The book Alliance for Change records the journey beginning from the formation of the partnership in the settlement of Sanjaynagar in Ahmedabad to project implementation (Tripathi, 1998), and the book Change after Alliance subsequently records the socio-economic impacts of water and sanitation (Tripathi \& Jumani, 2001). Various agencies and individuals (Dutta, 2000; SAATH, 1995; SHARDA Trust, 1995-2001; SHARDA Trust \& SAATH, 1999) have documented the impact of physical infrastructure for the Sanjaynagar settlement, which informed the current study.

Women in vulnerable households are likely to be engaged in food enterprises, water collection, fuel wood collection and water disposal/cleaning activities (Floro \& Swain, 2013; UNDP, 2006). Estimates by SEWA show that reducing water collection duration from two to one hour a day would enable women to earn an additional US\$ 100/year (UNDP, 2006). Whittington et al. (1990) developed a micro-economic framework showing that the value of time spent on hauling water in Ukunda village of Kenya was US\$ 0.31/hour in 1986. This is higher than the market wages of US\$ 0.25 /hour for unskilled labour (Whittington, Mu \& Roche, 1990). A study in the slums of Mumbai highlighted that women without income sources living with high earning husbands had limited bargaining power and were likely to change their decisions to follow the general consensus (Prabhu, 2010).

With access to basic services such as sanitation, energy, and water, women can potentially move up the productivity ladder and generate income for family which, in turn, 
can be used to purchase food and pay for services. With an elevated status of co-earners in the family women can take part in the decision making process. Limited work (SEWA, 2002; SHARDA, 1995-2001; Tripathi \& Jumani, 2001) explores gender issues through the discussion on time savings for water collection in Indian slums, but these studies suffer from limitations of sample size. This paper addresses these limitations by combining the agenda of infrastructure provision and gender equity and systematically documenting the effects of infrastructure using a comprehensive sample of Indian slums.

\section{METHODOLOGY}

(a) Sampling Framework

Five hundred household interviews were conducted in five slum settlements across India (see Table 1). Three of these (Ramdevnagar, Sanjaynagar and Pravinnagar) were serviced slums, with integrated infrastructure (in-house water and toilets, road surfacing, storm drainage and electricity) provided in the year of 1996. In 2006, data was collected for the socio-economic situation in both 1996 (no services) and 2006 (serviced). The other two slums (Hansol and Khokhra) had received no infrastructure intervention, and were designated as 'control slums'. Data were collected in Hansol for both the years of 1996 and 2006 for comparison with the serviced slums. However, due to a lack of cooperation from the residents in Khokhra data could only be collected for the year of 2006.

Interviewing 100 households in each slum is an extensive exercise and hence the slum selection, four slums from Ahmedabad city and one from Baroda city, was based on ease of access. Average income data from the independent study of CEPT (2004) allows average incomes in the selected slums to be compared. The CEPT study assessed impact and covered 17 SNP slums, 5 slums serviced through other interventions and 3 non-serviced slums in Ahmedabad i.e. a total of 25 slums. The average monthly per capita income in the 25 slums covered in the CEPT (2004) study when inflated to 2006 was US\$ 17. The average per capita monthly income in the 17 SNP slums in the CEPT study was noted to be an equivalent of 19 
US\$ in 2006. The average per capita income in Ramdevnagar was noted to be 20 US\$, thus the Baroda slum had income levels similar to the slums in Ahmedabad implying similar living conditions.

-Table 1 here

100 households were randomly selected from each slum based on a 95\% confidence level with a $10 \%$ margin of error that required a sample which ranged from 59 to 89 households in each of the five slums. Instead of varying the sample size for each slum, 100 households were interviewed. During the field work, a few houses did not express willingness to respond to the survey or provided limited information, which reduced our final sample to 474 households (Table 2).

-Table 2 here

The data for 1996 was obtained during the 2006 interviews, based on the respondents' memory of previous living conditions. In order to minimise the risk of response bias, only adults who had seen the process of change were questioned. All field team members were clearly briefed and requested not to interview children or respondents who did not recall previous living conditions. We also verified evidence from a few house interviews through discussions with their neighbours as we noted on site that the neighbours had extensive knowledge about the neighbourhood activities. The CEPT (2004) study which covered 25 slums noted that on average the residents had lived in the slum for 18.5 years which covers the study frame of 1996 to 2006. The CEPT (2004) study also interviewed the slum dwellers for a recall period of 4-6 years depending on the year of implementation in their study slums. During our study we noted that most of the households in the study slums had stayed back in the slum after the improvements. For example, in the serviced slums of Sanjaynagar, Ramdevnagar and Pravinnagar 90\% of the households had lived in the settlement for over ten years and hence were likely to have institutional memory. 
(b) Data Collection

Each face-to-face household interview took about 50 minutes, with 420 hours of cumulative interview time. In initial stages, the questionnaires from the World Bank (1997) living standards measurement study were reviewed. These have been used widely in various countries in both urban and rural setups but were too detailed and resource intensive to be directly applied in the slum setting. Questionnaires from other slum studies were reviewed (Ali, 1998; CEPT, 2004; SEWA, 2002) whilst developing the questions for this study. A pilot questionnaire was developed based on feedback from focus group discussions and the questionnaire was then modified to roll out at scale. The questionnaire ${ }^{1}$ was subdivided into various sections ranging from incomes to education and health. Men would be at work during the day time and women would be busy with water collection during the mornings. In order to ensure an equal split of respondents the interview timings were thus split between day and evening to ensure feedback was obtained from both groups.

(c) Analytical Framework

Traditionally quantitative methods can easily describe characteristics and highlight correlations in the sample population which represents a larger population. Whilst qualitative techniques such as ethnographical studies can provide details on topics which cannot be fully explored by data sets, the generalizability and replication of the findings is limited. We used the mixed-method approach to ensure that the findings we present are statistically representative and valid and then delve deeper into the household interviews to ensure that the behavioural aspect was being considered. The mixed-method approach has been used for combining statistical analysis and in-depth studies in resource limited settings (Adato, Lund \& Mhlongo, 2007; Howe \& McKay, 2007; London, Schwartz \& Scott, 2007). As poverty is multidimensional the combination of statistical validity and qualitative behavioural/motivational studies is suitable to synthesize and understand the questions of

\footnotetext{
${ }^{1}$ Copy of questionnaire available from first author
} 
'how and why?' In this study, the qualitative evaluation was indispensable in drawing out the gender imbalance in relation to infrastructure provision and has provided support to the quantitative analytics.

The qualitative analysis is underpinned by a statistical comparison of key indicators from the house interviews using the Mann-Whitney non-parametric test, the results of which are demonstrated in a visual matrix. Non parametric testing has been used previously on slum data for uni-sectoral studies concerning: the impact of water supply improvement in Manila (Aiga \& Umenai, 2002) and cooperative behaviour comparisons in South Africa (Kocher, Martinsson \& Visser, 2011). In order to avoid recall bias, the Mann-Whitney test has been used for data comparison between the current (2006) values for the serviced and non-serviced settlements. Thus key indicators from Khokhra and Hansol (both non-serviced) have been compared with the serviced settlements of Pravinnagar, Sanjaynagar and Ramdevnagar. In order to test beliefs and as a robustness check, we present the comparison between the preand post-project scenarios for Sanjaynagar, Ramdevnagar and Pravinnagar through the use of Wilcoxon Pairs Test. The differences between the 1996 and 2006 situation in the control nonserviced slum of Hansol was also tested, allowing a comparison with the results for the serviced slums. It was assumed that for $95 \%$ significance the range of rejection or acceptance is $\mathrm{p}=0.05$ for a one tailed test and the visual matrix was developed on this basis. The qualitative analysis enabled us to understand the impact of infrastructure provision and ascertain whether the changes to health, education, income, housing stock and gender related challenges were significant.

Based on the descriptive (qualitative) discussion, we then identify key indicators which are used to test our hypotheses using a multivariate regression approach. In the regression model we only use evidence from the year of 2006 to examine the relation between infrastructure and improvements in health, education, income and housing to avoid recall bias. There are eight linear regressions regressing distinctive dependent indicators (i.e. 
health, education, household income) on a same set of independent indicators and a series of other possible control indicators, which are potentially correlated with each other through their error terms. If this is verified, it means that a more efficient estimator can be obtained by estimating the equations jointly (Zellner, 1962). We therefore perform a Breusch-Pagan test of independence of error terms of the regressions. The null hypothesis was rejected $\left(\mathrm{Chi}^{2}(28)\right.$ $=103.73, \mathrm{p}<0.001$ for the main effect model and $\mathrm{Chi}^{2}(28)=108.97, \mathrm{p}<0.001$ for the moderation effect model), which suggests that the residuals of the eight regressions are correlated. We then employ the seemingly unrelated regressions (SUR), a system of linear regressions estimated jointly to account for the correlated residuals across the models. All indicators (except for the dichotomous indicators) included in the regression models are standardized with a mean of 0 and a standard deviation of 1 . To control for potential multicollinearity, we check the variance-inflation factors (VIFs) of the indicators in the models. The maximum value of VIF is 8.36 (less than 10), the mean VIF is 2.66 (less than 6) and the level of tolerance of all indicators is above 0.1 , which suggests that multicollinearity is not a problem in our data.

\section{SOCIOECONOMIC IMPACT}

a) Provision of services

Before the provision of services most houses used public taps, went to lakes and adjoining graveyards, borrowed water from neighbours, or had to provide labour in exchange for water. In the serviced areas most of the houses now have private taps. Previously, most houses lacked drainage facilities or used open drains for the passage of waste water. Defecation in open areas and disposal of waste water in rivers, open pits and lakes was common. Now most houses in serviced locations have piped sewerage. There is almost full coverage of either paved/concrete or surfaced road networks in all the developed slums. As with water and sanitation, coverage of storm drainage is extensive in developed slums and non-existent in the non-developed slums. In the serviced slums in India, roads have been 
designed with proper grades and cambers to double as open channels for storm drainage, though Pravinnagar also has underground piped storm drainage. The coverage of electricity increased substantially over the past ten years, therefore even in the non-serviced settlement of Hansol there is a significant increase in electricity coverage. Street light provisions in the slums of India were traditionally uncommon, but the current coverage has increased from non-existent to almost full coverage. Table 3 shows the status of provision of infrastructure in the study slums.

Table 3 here-

(b) Socio-economic Impact

i) Health and Education

Monthly medical expenditure is used as an indirect indicator of health, as it represents the costs (medication and doctor's fee) incurred due to illness. Data for monthly medical expenditure was collected and compared using the Mann-Whitney test. A substantial reduction in medical expenses in the three serviced slums following provision of services was noted, with the 2006 expenditure being lower for serviced than non-serviced slums. As a robustness check the 2006 and 1996 scenarios were compared using the Wilcoxon Pairs test and a similar trend was found. In particular in the non-serviced slum of Hansol, medical expenses have actually increased over time. The savings on medical spending in the serviced slums could potentially be diverted to education or housing stock improvement. Within the serviced slums, Ramdevnagar and Pravinnagar benefited from earlier NGO presence and health clinics, and yet the reduction in medical spending is comparable with the findings in Sanjaynagar. A more direct measure of health, the per capita disease rate, was determined. This is the annual number of disease incidents within each household divided by the family size. As shown in figure 1, the non-serviced settlements experience higher disease rates than the serviced houses in the year of 2006 and the disease rate has reduced in all the serviced areas. This finding is consistent with the observed reduction in monthly medical spending in 
the serviced households. In the quantitative model, population is accounted for and hence we use the household disease rate as the second indicator to represent health impact.

Figure 1 here

Table 4 shows school attendance and household spending on education. The male attendance figures are higher in the serviced areas as compared to both Khokhra and Hansol in the year of 2006. The average female attendance figure in the three serviced settlements (48 nos) is higher than the average attendance figures for non-serviced slums (32 nos) and slightly higher than the attendance in Khokhra. The decreases observed in female attendance in Pravinnagar are perhaps related to the 2002 riots, when safety concerns may have led to girls not being sent to school. Ramdevnagar slum is located in Baroda city which was not affected by the riots and female attendance figures appear to be high there. The female attendance in Khokhra therefore appears to be higher than those in Pravinnagar and lower than Ramdevnagar. The Mann-Whitney test gives non-significant results and hence we introduce an additional variable for literacy using ability to read as a proxy for literacy as we believe that this would discount the impact of riots. In this study, the percentage of those aged five years or above able to read newspapers in the local Gujarati or the national Hindi or English was used as a proxy for literacy. In the serviced slums there is a significant improvement in literacy as compared to the non-serviced slums, despite the fact that there was no increase in the educational infrastructure in those slums. There has been no significant change in literacy levels observed in the control slum of Hansol. The indicator of ability to read newspapers has been used as a proxy in the quantitative model.

Table 4 and 5 here

(ii) Income and Housing

A consumption measure of monthly household expenditure 'disposable income' is used as a proxy for income. Disposable income is estimated as the summation of monthly 
medical expenses, spending on food/groceries, utility bills, education costs, electricity charges, cable TV costs and investments in vehicles and housing. As shown in Table 5, the disposable income is higher in the serviced slums than in the non-serviced slums in the year of 2006. As an additional check, we noted a similar trend between the non-serviced and serviced scenarios with the rate of increase much higher than the control slum. This finding is validated by a similar survey carried out by SAATH in Pravinnagar which demonstrates that the average monthly income has increased by $56 \%$ (Joshi, 2002).

The serviced settlements have improved housing stock in terms of brick walling, tile/stone flooring and concrete roofing as compared to the non-serviced settlements in the year of 2006. The serviced settlements had mud walls, tin sheets and other inexpensive materials in the year of 1996 which have now been substituted by higher end materials through community investment. Surveys in Pravinnagar by SAATH also validate the improvement in housing stock with residents using on average Rs. 50,250 in the form of savings or loans from relatives (Joshi, 2002). In the study serviced slums the current house values range from US\$ 1900 to 4200 with the residents citing the provision of services as the primary incentive for investing in housing improvement (Parikh et al., 2012). A study of households in Lima confirms that the rate of improvement in housing stock roughly doubles with access to services and the effect far outweighs cost (Strassmann, 1984). In the Indian slums, the total investment by the community as a factor of initial government investment (i.e. the multiplier) ranges from 4.94 in Pravinnagar, through 8.23 in Sanjaynagar to 85 times in Ramdevnagar (Parikh et al, 2012).

As shown in figure 2, the monthly work days lost due to illness are lower in the serviced slums as compared to the non-serviced slums with a reduction noted in the serviced slums. Bad health and illnesses have an impact on productivity and livelihood if the working population is unable to work. In addition, with infant mortality, parents have to sacrifice income generating opportunities and take care of their children. Improvement of 
infrastructure and a cleaner environment in slums can potentially reduce the rate of illness and the work days lost due to illness. Similarly, the lack of flood water management can result in time and monetary losses for families. Figure 3 shows that the percentage of families losing time due to flooding is high in the non-serviced areas and this reduces significantly in the serviced slums. Similar trends were noted for monetary losses due to flooding.

-Figures 2 and 3 here-

The qualitative analysis demonstrates that infrastructure could potentially reduce time loss and improve productivity/disposable incomes of households. The resulting increase in disposable income is significant and has been selected as an indicator in the quantitative analysis.

\section{iii) Gender Effect}

The interviews highlighted specific difficulties faced by women (stomach problems, ill heath, loss of dignity and pride etc.) when the settlements were non-serviced. Women in slums experience stomach problems and ill health as they are too shy to defecate in the open during the day and have to restrain themselves until dark. The interviews show that the gender-related sanitation problems decreased substantially in serviced settlements and no such decrease was noted in the control slum of Hansol. Figure 4 shows a high rate of gender related sanitation problems in non-serviced slums as compared to the serviced slums.

Figure 4 here

Table 3 demonstrates that the number of private in-house toilets has increased significantly in the serviced projects as compared to the non-serviced areas with a similar trend demonstrated when the 2006 and 1996 results are compared. The residents are fully aware of the drawbacks of public toilets which range from inconvenience, fights and bad health. Studies (UNDP, 2006; WB, 2006) highlight challenges faced by women due to lack of sanitation facilities. 
As shown in Figure 5, the residents who now have private toilets note that safety was previously a major concern, and providing public toilets outside in vulnerable locations is not appropriate, especially for women using them at night. Women also report a lack of dignity involved in the use of public toilets especially in a cultural setting where harassment is still prevalent. In non-serviced settlements, the lack of house toilets meant that women queued for the public toilet or waited until night to defecate in the open thereby exposing themselves to possible emotional harassment (lewd comments and jokes) and assault. Similarly, the surveyed communities had clarity on the additional benefits (actual for the developed slums and perceived in the undeveloped slums) of water provision at household level rather than community level. As shown in Figure 6, comfort, cleanliness and time saving were perceived as the main benefits, though people also saw benefits in terms of health, privacy and safety. The challenges in relation to safety and privacy are faced by women as they bear the burden of water collection from public taps.

-Figures 5 and 6 here-

With inadequate sanitation systems, women traditionally spend at least one hour everyday on manually disposing kitchen/clothes washing water directly onto the streets. This is not only labour intensive for women but also unhygienic. In the serviced settlements women now use the time for housework and income generation activities. On average, in the sample surveyed, a house spent 2 hours to collect water, but with service provision there is a substantial time saving for women and children. The two hours saving has been confirmed by the SAATH survey in Pravinnagar (Joshi, 2002) and a study of Hyderabad slums (Sheshagiri, 2006). It was observed that in the serviced slums women use the time saved for housework, children's education, income generation and leisure. Figure 7 shows women bear a disproportionate burden of waste water disposal and water collection. 
In Pravinnagar, girls and elders stated that hygiene improved because of water and sanitation provisions (Joshi, 2002). Women also felt reduced stress after water and sanitation provision. This section highlights the challenges faced by women and the need to integrate infrastructure and gender issues. We therefore, assess the moderating effect of gender in our quantitative model to understand how the provision of infrastructure benefits women.

(c) Quantitative Assessment

(i) Indicators and Measures

The qualitative assessment enabled us to demonstrate the socio-economic impact of service provision (i.e. infrastructure) in the slum areas on the welfare of the poor with an emphasis on women and the girl child. The regression model and quantitative analysis is now used to explore causality. We look at mainly three aspects of social and economic outcomes of the service provision at the household level: the health condition, education attainment and income level. Each aspect has multiple dimensions to capture distinctive but partly related components of the construct.

- Health: The monthly medical cost (US\$) and the number of disease incidents in the current year (mortality) are used to represent health. The qualitative discussion in section 3 highlights the significance of monthly medical cost and mortality as a measure in the slum setting.

- Education: Education attainment is represented by both school/higher degree attendance and literacy. The attendance indicator is derived as the number of children from the age of 5 to 22 attending school/university. However Section 3 highlights that attendance alone does not imply knowledge gain and learning and thus literacy is used as the second indicator to represent education. In the slum setting where it is difficult to obtain census records, the ability to read newspapers has been used as a proxy for literacy. The number of household members above the age of five who can read newspapers in either the local language or English has been used in the regression model. 
- Income: In the slum setting the estimation of income is challenging as many households are engaged in manual labour or informal trade. There is also a tendency of respondents to under report income in interviews with a view of harnessing financial support and attracting aid. Therefore, the household monthly expenditure in US\$ i.e. disposable income has been used as a proxy for income. In addition to income from labour and trade, slum dwellers engage in barter and borrow money from family members during shocks and crises. Again, these are challenging to quantify and thus current house value (US\$) and current perceived land and house value (US\$) are introduced in the regression model. The current house value has been estimated through a review of household material typology and current construction costs in the serviced slums. For the non-serviced slums, respondents were asked to estimate the value of the house based on their local knowledge. The perceived land and house value is based on the respondents perception of how much they would sell their land and house for in the market.

- Gender: Section 3 highlighted the challenges faced by women and the girl child in slums. It is challenging to quantify gender effect in terms of improved gender health, perceived dignity and pride and potential time savings. For the regression model a more direct measure of female population was used to represent gender. Since we are assessing education, which is dependent on females of school going age, and income, which is dependent on the adult female population, we selected two moderating indicators to represent the gender effect: female population at the school/university age (5-22 years age) and above 22 years in a family.

The explanatory indicator is service provision which is the intervention in Sanjaynagar, Pravinnagar and Ramdevnagar. The intervention was provided in the form of integrated infrastructure at household level covering the components of water supply, sanitation, road, rain water management, electricity, solid waste management and street 
lighting. This indicator is a dummy coded as 1 if the household has access to integrated infrastructure

The control indicators are from two different levels: the household level and the slum level. At the household we control for family size and population. Since we are studying education which is dependent on children of school going age, health which is dependent on the well-being of infants and the elderly, and income which is dependent on the working individuals, we divided the population into varying age ranges to ensure each target group is represented.

At the slum level, control indicators were introduced to take into account regional variation in living conditions. We first control for the presence of developmental initiatives by NGOs, international organizations, and other institutions in the slums. This is to rule out the potential confounding effects brought forward by those programmatic activities. If a slum had the presence of a non-governmental organisation, residents association or community based organisation before the intervention year of 1996 it would imply that the residents in those slums would have higher capacity of organising themselves at the outset and could potentially attract investment and develop self-improvement programmes. We noted that the Baroda Citizens Council, SAATH and Kuchi Korve Samaj were involved in welfare activities pre-1996 in Ramdevnagar, Pravinnagar and Khokhra respectively and hence those slums are assigned a value of 1 in the analysis. The involvement of SEWA and SAATH was introduced in Sanjaynagar during the commencement of work rather than having a strong presence before 1996. Similarly, no organisational presence was noted in Hansol and hence we assigned a value of 0 to both Sanjaynagar and Hansol in our model.

The next slum level control indicator is the size of the slum community represented by the number of dwelling units in the settlement. One could argue that land ownership (tenure) could contribute to investments in housing and hence we have included land ownership as a control indicator. Land ownership is represented by the respondent's 
perception of land ownership as it is challenging in the informal setting of slums to see evidence of title deeds and land registry documentation partly as the documentation is nonexistent in most cases. The definitions and measurements of indicators used in the model are summarized in Table 6.

--------- Table 6 here -------

d) Mixed method results

A visual matrix based on non-parametric tests was used to demonstrate impact. Mann-Whitney compares the serviced and non-serviced slum in the year of 2006. In order to avoid recall bias, we rely primarily on the results of the Mann-Whitney test. We included for information the results of the Wilcoxon Pairs test to evaluate the significance of the socioeconomic transformation in the serviced slums before and after. In Tables 7 and 8 the boxes marked with '+' highlight the statistically significant positive changes and the boxes marked '-' highlight statistically significant negative changes. Non-significant changes, no change and changes which have not been measured have been marked as 'NS' in the tables.

Tables 7 and 8 here

In Table 7, which is based on the Mann-Whitney test, the 2006 results for the three serviced slums in India have been compared to the non-serviced settlements of Hansol and Khokhra. The matrix shows significant positive changes in a majority of the output socioeconomic indicators, highlighting the difference between the living conditions in the serviced and non-serviced settlements. The household interviews noted benefits of other components of infrastructure like roads, storm drainage and electricity.

As a robustness check, we use the Wilcoxon Pairs test, to assess if the comparison between 1996 and 2006 scenarios exhibit trends similar to the Mann-Whitney test. Table 8 demonstrates that the serviced slums have recorded positive changes in a majority of the key indicators as marked by ' + '. The provision of electricity improved through the local 
government's electrification programme in Hansol but none of the other services show significant positive change. Also the related socio-economic indicators in relation to maintenance, time loss and financial losses during floods have not improved in Hansol as compared to the serviced slums. The serviced settlements record an improvement in socioeconomic indicators whilst the non-serviced settlement of Hansol does not show an improvement in the same indicators.

Table 7 documents the improvement assessed by medical costs and per capita diseases. There has also been a significant improvement in literacy (ability to read) in the serviced slums after provision of services, and also in comparison to the non-serviced slums, despite the fact that there was no increase in the educational infrastructure in those slums. Non-significant improvements have been partly noted for spending on education, school attendance and private school attendance. There have been improvements in reported incomes, disposable incomes, expenditures and housing stock in the serviced slums. The evidence in relation to improvement in incomes and housing stock is compelling.

The indicator of gender-related health problems for women was assessed and found to be significant, i.e. in the serviced slums the health problems were significantly lower than the non-serviced slums in 2006. A comparison between the serviced and non-serviced slums for the 1996 and 2006 scenario also follow a similar trend. The significant reduction of gender related health problems for women demonstrate the value and need of conducting gender specific research to understand the impact of infrastructure. In addition to the qualitative discussion which demonstrates socio-economic impact, the quantitative analysis was used to establish causality and to quantify the influence of infrastructure. The descriptive statistics and correlations of the indicators are reported in tables 9 and 10 respectively. As shown in table 10 , there is no worryingly large correlation between any pair of independent indicators. It therefore confirms the finding of variance-inflation analysis and further rules out the possibility of multicollinearity issues in our econometric analysis. 
There are eight linear regressions regressing distinctive dependent indicators (i.e. health, education, household income) on a same set of independent indicators and a series of other possible control indicators. Models from 1a to $8 \mathrm{a}$ are specified as the baseline models including only control indicators. Models from $1 \mathrm{~b}$ and $8 \mathrm{~b}$ include the main explanatory indicators and test the main effects of service provision on the households' health, education and income, respectively. The results from all the models $1 \mathrm{~b}$ to $8 \mathrm{~b}$ are statistically significant and report the positive impact of service provision. The models $1 \mathrm{~b}$ and $2 \mathrm{~b}$ in Table 11 show the estimation results of the influence of service provision on household's health condition. As predicted, access to services significantly reduces health costs for households $(-0.32$, $\mathrm{p}<0.05)$ and per capita disease incidents $(-1.02, \mathrm{p}<0.01)$. As to the effect of services on the level of education, models $3 \mathrm{~b}, 4 \mathrm{~b}$ and $5 \mathrm{~b}$ show that reading capability of people above age 5 $(0.57, \mathrm{p}<0.001)$, male $(0.61, \mathrm{p}<0.001)$ and female school/university attendance $(0.39, \mathrm{p}<0.01)$ increase due to the impact of service provision. The results are all statistically significant.

There are three indicators captured at household income level. As demonstrated by models $6 \mathrm{~b}, 7 \mathrm{~b}$ and $8 \mathrm{~b}$, service provision has a significant effect on family's disposable income $(0.67, \mathrm{p}<0.001)$, house value $(0.73, \mathrm{p}<0.001)$ and also land and house value $(0.47$, $\mathrm{p}<0.001)$. All the effects are significant at the level of $\mathrm{p}<0.001$. The impact of infrastructure is therefore fully supported by the results shown above.

Table 11 here-

The regression models from $1 \mathrm{c}$ to $8 \mathrm{c}$ in Table 11 test the moderation effects of gender on the relationship between the service provision and its socio-economic benefit. We divide the female population into two groups namely 5-22 and $22+$ so that we can evaluate gender impact for both children and adult population and capture impact in relation to health and education. We also include the interaction effect of gender on the relationship between 
service provision and household's health, education and economic condition. The estimated moderation effects have shown mixed results. Specifically, the number of females above age 22 in a family intensifies the negative impact of service provision on family's health cost ( $0.17, \mathrm{p}<0.1)$ and disease incidences $(-0.19, \mathrm{p}<0.1)$ as it is shown in models $1 \mathrm{c}$ and $2 \mathrm{c}$, meaning that it reduces family's health cost and disease incidences even further. Female population has no impact on the relationship between service and reading capability of family members (see model 3c), whilst female population between age 5 and 22, has an opposing moderating effect on impact of service provision on male and female school attendants, such that it attenuates the effect on male attendants $(-0.15, \mathrm{p}<0.1)$ and enhances the effect on female attendants $(0.31, \mathrm{p}<0.001)$ as shown in models $4 \mathrm{c}$ and $5 \mathrm{c}$. We find, however, that there is no evidence showing that female population has any impact on the relationship between service provision and family economic conditions as shown in models $6 \mathrm{c}, 7 \mathrm{c}$ and $8 \mathrm{c}$.

\section{DISCUSSION}

This study provides evidence of the significant socio-economic impact of integrated infrastructure. The visual matrix highlights the outcomes of infrastructure and significance levels through a statistical comparison. The regression model establishes causality and demonstrates that infrastructure directly improves health, education and housing simultaneously. The regression model shows that holding other variables constant, provision of infrastructure would lead to about 0.32 units of standard deviation decreases in family health cost and 1.02 units of standard deviation decreases in the disease incidence. In other words, other things being equal, families that receive infrastructure services would spend nearly 2 US\$ less per month than those that did not receive the corresponding service, which is about $26 \%$ less than the average health spending (i.e., 7.65 US\$) of the families in our sample. The incidence of disease for families receiving service is almost 1 case less than those have no access to the service in the year of observation. This is about $50 \%$ reduction relative to the average level (i.e. 1.75 cases), which is substantial. 
In terms of the impact on education, the infrastructure service provision results in about 0.57 units of standard deviation increase in reading capability of family members above the age of 5, 0.61 and 0.39 units of standard deviation increases in the male and female school attendance respectively. Intuitively, these numbers indicate that, other things being equal, families that have access to the infrastructure services would have 1 more person above the age 5 who has the ability to read compared to the families without access to the service. This is again a huge improvement $(62 \%)$ relative to the average capability, as on average, less than 2 people above age 5 per household were able to read according to our sample. Similarly, service provision significantly increases the level of school/university attendance of school age family members, for both male ( $82 \%$ relative to the average level) and female (66\% relative to the average level).

The service provision also showed strong influence on a household's income level. Other things being equal, access to services would result in 0.68 units of standard deviation (about 34 US\$, a 36\% increase relative to the average level) increase in a family's monthly disposable income, 0.73 units of standard deviation increase in a family's house value (about 1728 US\$, an $80 \%$ increase relative to the average level) and 0.47 units of standard deviation increase in land and house value (about 1285 US\$, a 59\% increase relative to the average level).

Within the slum setting there is inequity in terms of gender bias. We examined how households were affected by infrastructure provision with the increase of women population in a family. The study highlighted improved health and education for women as a result of infrastructure. More specifically, among those families that received infrastructure services, for every three units of standard deviation (i.e. about 2 people) increase in the female population above age 22 in a family, we observe a reduction in both monthly health costs (about 3 US\$) and disease incidence (about 0.5 cases). For every unit standard deviation (i.e. about 1 person) increase in the school age (age 5-22) female population in a family, the 
female school attendance goes up by about 1 person. To show with more clarity the moderating role of gender, we plotted the moderation effect of female population on the relationship between service provision and households' welfare (i.e. health and female education) across three different levels of female population in two age categories (i.e. mean value, and one standard deviation below and above the mean value). Figures 8 and 9 show clearly the effect of infrastructure service on households' health conditions, and that as female population increases the increases in the level of female education and the decreases in health costs and disease incidence are greater as a result of provision of services.

\section{----- Figures 8 and 9 here------}

The income and housing asset indicators are not significantly positive. One possible explanation could be that women are still not gainfully engaged in mainstream employment and are not the primary bread winners of the family. A comparison of male and female attendance figures (Table 4) indicates the school attendance figures are higher for the male child. The attendance figures were also checked with a similar trend of lower school attendance with the girl child. Thus, women are more likely to be engaged in manual labour with low daily wages. It is therefore likely that the income and housing asset improvement for households with a higher proportion of women will only take place when a generation of women manage to attend school and capitalise on the cleaner environment.

To improve health and education, the provision of healthcare and educational facilities is appropriate. However, in the serviced slums, despite the presence of health clinics, the medical expenditure reduced after infrastructure provision. In the control slums of Hansol, the medical expenses have increased during the same time. Similarly the educational facilities in the proximity of the serviced slums have remained unchanged and with integrated infrastructure being the only intervention, it can be established that the improvements in 
literacy (ability to read) may be linked to infrastructure provision that reallocates time and effort towards capability development.

The CEPT (2004) study which included 17 SNP (Parivartan) slums noted that the residents were highly satisfied with the provision of services but had limited knowledge about the softer services/social infrastructure intervention. The softer services did not have a strong impact on the residents possibly due to poor co-ordination between the government and NGO's (CEPT, 2004). Institutional challenges in the SNP have also been noted by Das and Takahashi (2009). The CEPT study noted that $49 \%$ of the SNP respondents were aware of the presence of SEWA in the programme and $24 \%$ of the respondents have availed of the micro-credit facilities offered by SEWA. In 2002, the Mahila Housing SEWA Trust with USAID conducted household interviews in 297 houses in three settlements in Ahmedabad (SEWA, 2002). The study looked at two settlements (Babalablabinagar and Sinheshwarinagar) where services have been implemented and one adjoining settlement (Madrasi Ni Chali) which is non-serviced. SEWA (2002) has reported the positive impact of infrastructure interventions. This is perhaps remarkable coming from an agency specialising in micro-credit programmes.

Land ownership (tenure) is another important factor, which one can argue, may have influenced the subsequent improvements in housing stock. The household interviews show that whilst land ownership (tenure) was one of the reasons for community investments in housing stock, it was not the most cited response. The regression model includes land ownership as a control indicator to ensure that land ownership is accounted for.

We used the variable of perceived land value to discuss the potential asset creation through the process of infrastructure provision and the subsequent housing upgrading process. An increase in perceived land value could result in cross subsidy and improved potential to borrow in the market. The CEPT (2004) study also includes a study of perceived 
property values and found that irrespective of ownership the property prices and rental values had increased in the serviced slums.

One can argue that economic growth could be an influencing factor in say the increase of incomes. Whilst one argument for the increase in incomes could be the natural economic growth, the current incomes in the serviced slums are higher than the non-serviced slums in 2006. The comparison of the before and after scenario in the serviced slums also indicate a similar trend of increase. There appears to be no other noticeable causes between 'before' and 'after' or between serviced and non-serviced to account for this difference other than provision of infrastructure. In fact the micro-credit lending organisation SEWA (2002) who was a partner in the slum networking project also acknowledge the role of infrastructure in improving the quality of life in their study.

The paper demonstrates that infrastructure directly acts as a driver for improved wellbeing and increased productivity and asset creation with the potential to benefit women and the girl child. This goes against the conventional wisdom of economic growth being the driver for well-being and improved quality of life. Infrastructure can directly result in human development and well-being (Straub, 2008; Szreter, 2005). In particular for women and girl children, there are benefits in relation to education and health improvements which could potentially improve living conditions for the entire family. An investment of circa US\$ 500 per family for infrastructure not only improved health and education but generated community investments worth US\$ 1900-4200 in terms of improved housing and assets in the study slums (Parikh et al, 2012). Such a return or multiplier on investment is rare on developmental projects in the slum setting.

\section{POLICY CONTRIBUTION}

The study provides a robust mixed-method framework for assessment of the socioeconomic impact of infrastructure in slums. The qualitative visual matrix provides practitioners, academics and policy makers a toolkit which is visually powerful and clear and 
based on systematic review of socio-economic indicators in slums. The template could be used to study other slum settlements which are served by similar or different forms of interventions. The regression model establishes causality and provides practitioners with a decision making framework which would enable decision makers to quantify the impact of infrastructure.

The comprehensive analysis of the impact of infrastructure and gender equity on such a scale is the prime contribution of this study. We establish that poverty is not insuperable and that there are both the means and the resources to overcome it through gender-sensitive infrastructure interventions. Interventions in health, education and employment can improve lives in slums but they need to be preceded by investment in infrastructure. The provision of basic services such as water and sanitation can be used as a leverage to generate community investments in creating housing stock (Parikh et al, 2012a). Strassman (1984) demonstrated that the economic ability to improve housing matters less than willingness to pay which is triggered by access to water and sanitation. The differences in income levels determine the nature of improvements in housing stock though the rate of improvement roughly doubled in Lima with the provision of infrastructure (Strassman, 1984).

Policy changes which improve infrastructure (water and sanitation) in developing countries have a positive impact on health, education, income and welfare (Calderón \& Servén, 2004; UNDP, 2006; WB, 2004). Researchers are calling for innovations in provision, governance, and business models for improving services in disenfranchised communities (e.g. George, McGahan \& Prabhu, 2012). Innovations in products, business models and the delivery of services using government or NGO partners could potentially accommodate gender-sensitive requirements for such infrastructure. Such targeted interventions could empower slum dwellers to shift from inferior 'slum-like' living conditions to a clean environment with improved housing, health and educational facilities. Furthermore, if infrastructure projects are targeted towards women, it is likely that women 
will benefit as they traditionally bear the burden of house cleaning, water collection, and waste disposal. The study of gender bias in infrastructure provision can help direct aid agencies to promote investment in gender friendly infrastructure that helps maintain pride, dignity and safety. 


\section{REFERENCES}

1. Adato, M., Lund, F., \& Mhlongo, P. (2007). Methodological innovations in research on the dynamics of poverty: A longitudinal study in KwaZulu-Natal, South Africa. World Development, 35(2), 247-263.

2. Aiga, H., Umenai, T. (2002). Impact of improvement of water supply on household economy in a squatter area of Manila, Social Science \& Medicine 55, 627-641.

3. Ali. S., (1998). Environmental Scenario of Delhi Slums, Council for Social Development, Gyan Sagar Publications.

4. Asthana, S. (1995). Variations in poverty and health between slum settlements: contradictory findings from Visakhapatnam, India, Social Science Medicine,40(2), 177188.

5. Bhattacharya, A., Romani, M. \& Stern, N. (2012). Infrastructure for development: meeting the challenge, Policy Paper, Centre for Climate Change Economics and Policy, Grantham Research Institute on Climate Change and the Environment in collaboration with Intergovernmental group of twenty four.

6. Butala, N., VanRooyen, M. \& Patel, R. (2010). Improved health outcomes in urban slums through infrastructure upgrading, Social Science \& Medicine 7, 935-940.

7. Calderón, C. \& Servén, L. (2004). The Effects of Infrastructure Development on Growth and Income Distribution, World Bank, Working Paper 3400: WPS3400.

8. Caldwell, J. (1986). Routes to low mortality in poor countries. Population and Development Review. Vol. 12 (2), 171-220.

9. Centre for Environment, Planning and Technology (CEPT). (2004). Wealth and wellbeing impacts of slum upgrading and improved service delivery to the poor: A case study of slum networking project, Ahmedabad, India. Prepared by School of Planning, Submitted to Water and Sanitation Program-South Asia World Bank. 
10. Das, A. K., \& Takahashi, L. M. (2009). Evolving institutional arrangements, scaling up, and sustainability emerging issues in participatory slum upgrading in Ahmedabad, India. Journal of Planning Education and Research, 29(2), 213-232.

11. Dercon, S. \& Singh, A. (2013). From nutrition to aspirations and self-efficacy: gender bias over time among children in four countries, World Development 45, 31-50.

12. Dutta, S. (2000). Partnerships in urban development: a review of Ahmedabad's experience, Environment \& Urbanization, Vol. 12(1), 13-26.

13. Esfahani, H. \& Ramirez, M. (2003). Institutions, infrastructure and economic growth, Journal of Development Economics, 70: 443-477.

14. Fay, M., Leipzigerm, D., Wodon, Q. \& Yepes, T. (2005) Achieving child-health-related Millennium Development Goals: The role of infrastructure, World Development, 33: $1267-1284$.

15. Feler, L. \& Henderson, J. (2011). Exclusionary policies in urban development: Underservicing migrant households in Brazilian cities, Journal of Urban Economics, 69, 253272.

16. Floro, M. \& Swain, R. (2013). Food Security, Gender, and Occupational Choice among Urban Low-Income Households, World Development, 42, 89-99.

17. George, G., McGahan, AM., Prabhu, JC. 2012. Innovation for inclusive growth: Towards a theoretical framework and research agenda. Journal of Management Studies, 49(4): $661-683$.

18. Government of India GOI (2010). Report of the Committee on Slum Statistics/ Census, Government of India, Ministry of Housing and Urban Poverty Alleviation.

19. Gulyani, S. \& Talukdar, D. (2008). Slum Real Estate: The Low-Quality High-Price Puzzle in Nairobi’s Slum Rental Market and its Implications for Theory and Practice, World Development, 36, 1916-1937. 
20. Howe, G., \& McKay, A. (2007). Combining quantitative and qualitative methods in assessing chronic poverty: The case of Rwanda, World Development, 35(2), 197-211.

21. Joshi, R. (2002). Integrated slum development: Case of Pravinnagar-Guptanagar in Kundu, A. and Mahadevia, D. (ed.) Poverty and vulnerability in a globalising metropolis Ahmedabad. Manak Publications, 268-308.

22. Kocher, M., Martinsson, P. \& Visser, M. (2012). Comparison between an urban slum and a non-slum area social background, cooperative behaviour, and norm enforcement, Journal of Economic Behaviour \& Organization 8, 341- 354.

23. Lall, S., Lundberg, M. \& Shalizi, Z (2008). Implications of alternate policies on welfare of slum dwellers: Evidence from Pune, India, Journal of Urban Economics 63, 56-73.

24. London, A. S., Schwartz, S., \& Scott, E. K. (2007). Combining quantitative and qualitative data in welfare policy evaluations in the United States. World Development, $35(2), 342-353$.

25. Moser, C. O. N. (1998). The asset vulnerability framework: Reassessing urban poverty reduction strategies. World Development, Vol. 26 (1), 1-19.

26. Parikh, P. (2008). Impact of Integrated Water and Environmental Sanitation Infrastructure on Poverty Alleviation. PhD thesis, Cambridge University, Cambridge.

27. Parikh, P. \& McRobie, A. (2009). Engineering as a Tool for Improving Human Habitat, International Journal of Management and Decision Making, Vol.10, pp. 270-281.

28. Parikh, P. H., Parikh, A. \& McRobie. (2012). Role of Infrastructure in improving human settlements. Proceedings of the ICE- Urban Design and Planning, 166 (2): 101-118, DOI: 10.1680/udap.10.00038.

29. Parikh, P., Chaturvedi, S. \& George, G. (2012a). 'Empowering change: The effects of energy provision on individual aspirations in slum communities, Energy Policy, 50: 477485. 
30. Prabhu, V. (2010). Tests of intra household resource allocation using a CV framework: A comparison of husbands' and wives' separate and joint WTP in the slums of NaviMumbai, India. World Development, 38, 606-619.

31. SAATH (1995). A profile of Sanjaynagar. Survey of Sanjaynagar, Ahmedabad.

32. Self Employed Women's Association (SEWA) (2002). Parivartan and its impact: A partnership programme of infrastructure development in slums of Ahmedabad city, Accessed from http://www.sewahousing.org/index.php?p=studies, September, 2014.

33. Sen, A. (1999). Commodities and Capabilities. Oxford University Press.

34. Sen. A (1984). The living standard. Oxford Economic Papers, New Series, Vol. 36, Supplement: Economic theory and Kicksian Themes, Nov. 1984, 74-90.

35. Schillebeeckx, S., Parikh, P., Bansal, R., George, G. (2012). An integrated framework for rural electrification: Adopting a user-centric approach to business model development, Energy Policy, 48: 687-697.

36. Seshagiri, R. M. (2006). Household preferences and willingness to pay water services in Hyderabad, India. PhD thesis Cambridge University. Approved June 2006.

37. SHARDA Trust \& SAATH (1999). Sanjay Nagar, A postscript. Ahmedabad.

38. SHARDA Trust (1995-2001). SHARDA Trust A Profile. Ahmedabad.

39. Strassmann, P. (1984). The timing of urban infrastructure and housing improvements by owner occupants, World Development, 12: 743-753.

40. Straub, S. (2008). Infrastructure and Growth in Developing Countries: Recent advances and research challenges, The World Bank, Policy Research Working Paper 4460: WPS4460, January 2008.

41. Szreter, S. (2005). Health and wealth. Studies in History and Policy, University of Rochester Press.

42. Tripathi, D. (1998). Alliance for Change - Slum Upgrading Experiment in Ahmedabad, Tata McGraw Hill. 
43. Tripathi, D. \& Jumani, J. (2001). Change After Alliance Sequel to Alliance for Change, Tata McGraw Hill.

44. United Nations Development Programme (UNDP) (2006). Human Development Report (HDR): Beyond scarcity: power, poverty and the global water crisis. New York.

45. United Nations (UN) (2011). The Millennium Development Goals Report 2011. New York

46. UN-HABITAT (2003). The Challenge of Slums, Global Report on Human Settlements, 2003, United Nations Human Settlements Programme, UNHABITAT.

47. Whittington, D., Mu, X. \& Roche, R (1990). Calculating the value of time spent collecting water: Some estimates for Ukunda, Kenya. World Development 18: 269-280.

48. World Bank. (WB) (1994). World Development Report: Infrastructure for development. Oxford University Press, New York.

49. World Bank. (WB) (2004). World Development Report: Making services work for poor people. Oxford University Press, New York.

50. World Bank. (WB) (2006). World Development Report: Equity and development. Oxford University Press, New York.

51. Zellner, A. (1962). An efficient method of estimating seemingly unrelated regressions and tests for aggregation bias. Journal of the American Statistical Association, 57(298): 348-368. 
Table 1 Summary table of slum settlements in India

\begin{tabular}{|c|c|c|c|c|c|}
\hline $\begin{array}{l}\text { Name of } \\
\text { Slum }\end{array}$ & $\begin{array}{l}\text { Location } \\
\text { City }\end{array}$ & $\begin{array}{l}\text { Integrated } \\
\text { Infrastructure } \\
\text { provision }\end{array}$ & $\begin{array}{l}\text { No. of dwelling \& } \\
\text { community } \\
\text { amenity units }\end{array}$ & Land Ownership & $\begin{array}{l}\text { Density } \\
\text { Persons } \\
\text { /hectare }\end{array}$ \\
\hline Sanjaynagar & Ahmedabad & Yes & $181[1]$ & Municipal Corporation[3] & $459[5]$ \\
\hline Ramdevnagar & Baroda & Yes & $779[1]$ & Government [4] & $218[5]$ \\
\hline Pravinnagar & Ahmedabad & Yes & $1200[2]$ & Private [3] & $474[5]$ \\
\hline Khokhra & Ahmedabad & No & $141[2]$ & Private [3] & $409[5]$ \\
\hline Hansol & Ahmedabad & No & $320[2]$ & State Government [3] & $373[5]$ \\
\hline
\end{tabular}

Source:

[1] Himanshu Parikh Consulting Engineers

[2] Ahmedabad Municipal Corporation, 2005

[3] Ahmedabad Municipal Corporation, 2006

[4] Ramdevnagar: A Slum decides its Fate, Baroda Citizens Council

[5] Density based on areas measured from topographical surveys and population estimated from number of dwellings and average family size

NOTE 1: In the settlements of Sanjaynagar, Pravinnagar and Ramdevnagar household water, drainage, toilets, roads, storm drainage and electricity were included in the scope of works. 
Table 2 Sampling frame for the study slums

\begin{tabular}{lllllll}
\hline Name of & Total & Sample & Actual & Sample \\
Slum & $\begin{array}{l}\text { dwellings } \\
\text { size }\end{array}$ & $\begin{array}{l}\text { Ample } \\
\text { size }\end{array}$ & $\begin{array}{l}\text { Average } \\
\text { for }\end{array}$ & $\begin{array}{l}\text { Estimated } \\
\text { family } \\
\text { size }\end{array}$ & $\begin{array}{l}\text { Population } \\
\text { size }\end{array}$ \\
\hline Sanjaynagar & 181 & 63 & 100 & 96 & 6.8 & 1238 \\
Ramdevnagar & 799 & 86 & 100 & 99 & 5.5 & 4355 \\
Pravinnagar & 1200 & 89 & 100 & 93 & 6.0 & 7200 \\
Khokhra & 153 & 59 & 100 & 94 & 6.4 & 981 \\
Hansol & 320 & 74 & 100 & 93 & 5.8 & 1866 \\
\hline
\end{tabular}

NOTE 1: The family size represents the average family size from the sample families. The estimated total population has been obtained by multiplying the number of dwellings/units with sample family size. 
Table 3 Infrastructure status before and after intervention

\begin{tabular}{|c|c|c|c|c|c|}
\hline & $\begin{array}{c}\text { Sanjaynagar } \\
\%\end{array}$ & $\begin{array}{c}\text { Pravinnagar } \\
\%\end{array}$ & $\begin{array}{c}\text { Ramdevnagar } \\
\%\end{array}$ & $\begin{array}{c}\text { Khokhra } \\
\%\end{array}$ & $\begin{array}{c}\text { Hansol } \\
\%\end{array}$ \\
\hline \multicolumn{6}{|c|}{ Water } \\
\hline 1996 & 1.1 & 1.1 & 1.0 & & 1.5 \\
\hline 2006 & 93.7 & 97.8 & 96.0 & 25.5 & 1.1 \\
\hline \multicolumn{6}{|c|}{ Sanitation } \\
\hline 1996 & 1.1 & 1.1 & 15.2 & & 1.5 \\
\hline 2006 & 93.7 & 100 & 91.9 & 39.4 & 2.2 \\
\hline \multicolumn{6}{|c|}{ Private Toilet } \\
\hline 1996 & 1.1 & 8.6 & 15.2 & & 1.5 \\
\hline 2006 & 96.0 & 100 & 96.0 & 27.6 & 1.1 \\
\hline \multicolumn{6}{|l|}{ Road } \\
\hline 1996 & 1.1 & 1.1 & 1.0 & & 1.5 \\
\hline 2006 & 95.8 & 97.8 & 96.0 & 3.2 & 2.2 \\
\hline \multicolumn{6}{|c|}{ Storm } \\
\hline 1996 & 1.1 & 3.2 & 2.0 & & 0.0 \\
\hline 2006 & 89.5 & 100.0 & 96.0 & 12.8 & 3.2 \\
\hline \multicolumn{6}{|c|}{ Electricity } \\
\hline 1996 & 7.4 & 66.7 & 53.5 & & 1.5 \\
\hline 2006 & 88.4 & 100.0 & 99.0 & 76.6 & 58.1 \\
\hline \multicolumn{6}{|c|}{ Street lighting } \\
\hline 1996 & 5.3 & 1.1 & 1.0 & & 1.0 \\
\hline 2006 & 89.5 & 58.1 & 97.0 & 1.0 & 1.0 \\
\hline
\end{tabular}


Table 4 Improvement in Education

\begin{tabular}{|c|c|c|c|c|c|}
\hline & Sanjaynagar & Pravinnagar & Ramdevnagar & Khokhra & Hansol \\
\hline \multicolumn{6}{|c|}{$\%$ Ability to read newspapers $5+$ population $(\%)$} \\
\hline 1996 & $10 \%$ & $39 \%$ & $31 \%$ & NA & $2 \%$ \\
\hline 2006 & $20 \%$ & $58 \%$ & $60 \%$ & $17 \%$ & $4 \%$ \\
\hline \multicolumn{6}{|c|}{$\%$ Male Attendance (4-22 years old) } \\
\hline 1996 & $27 \%$ & $57 \%$ & $62 \%$ & NA & $12 \%$ \\
\hline 2006 & $46 \%$ & $53 \%$ & $68 \%$ & $37 \%$ & $19 \%$ \\
\hline \multicolumn{6}{|c|}{$\%$ Female Attendance (4-22 years old) } \\
\hline 1996 & $24 \%$ & $52 \%$ & $55 \%$ & NA & $5 \%$ \\
\hline 2006 & $27 \%$ & $32 \%$ & $53 \%$ & $32 \%$ & $11 \%$ \\
\hline \multicolumn{6}{|c|}{ Male Attendance (4-22 years old) } \\
\hline 1996 & 35 & 67 & 71 & NA & 10 \\
\hline 2006 & 75 & 63 & 73 & 52 & 24 \\
\hline \multicolumn{6}{|c|}{ Female Attendance (4-22 years old) } \\
\hline 1996 & 24 & 55 & 54 & NA & 7 \\
\hline 2006 & 40 & 38 & 67 & 47 & 17 \\
\hline
\end{tabular}

NOTE: * The drop in attendance figures may possibly be due to riots as parents may have safety concerns in relation to sending girls to school. 
Table 5 Improvement in income and housing stock

\begin{tabular}{|c|c|c|c|c|c|}
\hline & nagar & Pravinnagar & Ramdevnagar & Khokhra & Hansol \\
\hline Income Inflated 1996 & 83 & 107 & 85 & NA & 42 \\
\hline Income 2006 & 91 & 121 & 110 & 76 & 45 \\
\hline \multicolumn{6}{|l|}{ Brick Wall \% } \\
\hline 1996 & 1 & 12 & 3 & NA & 1 \\
\hline 2006 & 99 & 99 & 99 & 30 & 14 \\
\hline \multicolumn{6}{|l|}{ Tile/Stone Flooring \% } \\
\hline 1996 & 4 & 6 & 2 & NA & 1.5 \\
\hline 2006 & 78 & 88 & 84 & 45 & 2.2 \\
\hline \multicolumn{6}{|l|}{ Concrete Roof \% } \\
\hline 1996 & 1.1 & 8.6 & 15.2 & NA & 1.5 \\
\hline 2006 & 96.0 & 88 & 96.0 & 27.6 & 1.1 \\
\hline \multicolumn{6}{|c|}{ Average House Value (Construction Cost US\$) } \\
\hline Inflated 1996 & 1201 & 2415 & 2847 & NA & 103 \\
\hline 2006 & 1994 & 3550 & 4174 & 872 & 321 \\
\hline \multicolumn{6}{|c|}{ Average perceived Land and House Value US\$ } \\
\hline Inflated 1996 & 402 & 2175 & 1035 & NA & 189 \\
\hline 2006 & 1879 & 4138 & 2766 & 1265 & 636 \\
\hline
\end{tabular}


Table 6 Indicators and measurements

\begin{tabular}{|l|l|}
\hline Indicator name & Measurement \\
\hline Dependent Indicator & \\
\hline Health & \\
\hline HEALTH COST & Monthly health cost per household (in US\$) \\
\hline DISEASE & Disease incidence per household in the current year \\
\hline Education & Ability to read newspaper 5+ age per household \\
\hline READ 5+ & Male school/university attendance 5-22 age per household \\
\hline MALE ATTEN & Female school/ university attendance 5-22 age per household \\
\hline FEMALE ATTEN & \\
\hline Income & Disposable income per household per month (in US\$) \\
\hline DIS INCOME & Value of current house construction (in US\$) \\
\hline HOUSE VALUE & Perceived Land and house value (in US\$) \\
\hline LAND VALUE & \\
\hline Independent Indicator & Intervention: dummy coded as Yes=1, No=0 \\
\hline SERVICE & Number of female population between age 5 and 22 in a family \\
\hline FEMALE POP 5-22 & Number of female population above age 22 in a family \\
\hline FEMALE POP 22+ & \\
\hline Control Indictors & \\
\hline Household level & Total number of population in a family \\
\hline FAMILY SIZE & Number of male population under age 5 in a family \\
\hline INFANT POP MALE & Number of female population under 5 in a family \\
\hline INFANT POP FEMALE & Number of population between age 5 and 20 in a family \\
\hline POP 5-20 & Number of population between age 21 and 36 in a family \\
\hline POP 22-36 & Number of population between age 37 and 52 in a family \\
\hline POP 37-52 & Number of population between age 53 and 68 in a family \\
\hline POP 53-68 & Number of population above age 69 in a family \\
\hline POP 69+ & Number of dwellings in the slum \\
\hline Slum level & Perceived ownership of land: dummy coded at Yes=1 and No=0 \\
\hline INSTITUTION & \\
\hline DWELLING & \\
\hline LAND OWNERSHIP & \\
\hline & \\
\hline
\end{tabular}


Table 7 Mann-Whitney test results for outputs for the year of 2006

\begin{tabular}{|c|c|c|c|c|c|c|}
\hline & \multicolumn{2}{|c|}{ Sanjaynagar } & \multicolumn{2}{|c|}{ Ramdevnagar } & \multicolumn{2}{|c|}{ Pravinnagar } \\
\hline & Hansol & Khokhra & Hansol & Khokhra & Hansol & Khokhra \\
\hline \multicolumn{7}{|l|}{ WATER } \\
\hline Water supply pipes have increased & + & + & + & + & + & + \\
\hline \multicolumn{7}{|l|}{ SEWERAGE } \\
\hline Sewerage pipes have increased & + & + & + & + & + & + \\
\hline Private/individual toilets has increased & + & + & + & + & + & + \\
\hline \multicolumn{7}{|l|}{ ROADS } \\
\hline Provision of roads has increased & + & + & + & + & + & + \\
\hline \multicolumn{7}{|l|}{ STORM DRAINS } \\
\hline Storm drainage provisions has increased & + & + & + & + & + & + \\
\hline Time loss due to rains has reduced & + & + & + & + & + & + \\
\hline Money loss due to rains has reduced & + & + & + & + & + & + \\
\hline
\end{tabular}

\section{ELECTRICITY}

\begin{tabular}{|l|l|l|l|l|l|l|}
\hline Individual electricity connections increase & + & + & + & + & + \\
\hline
\end{tabular}

\section{STREETLIGHTING}

\begin{tabular}{|l|l|l|l|l|l|l|l|}
\hline Street lighting provisions have increased & + & + & + & + & + \\
\hline
\end{tabular}

\section{HEALTH}

\begin{tabular}{|l|c|c|c|c|c|c|}
\hline Monthly house medical spending reduced & + & + & + & + & + & + \\
\hline Per capita total disease rate has reduced & + & + & + & + & + & + \\
\hline
\end{tabular}

EDUCATION
\begin{tabular}{|l|c|c|c|c|c|c|}
\hline Ability to Read/literacy increased & + & NS & + & + & + & + \\
\hline Male attendance has increased & + & + & + & + & + & NS \\
\hline Female attendance has increased & + & NS & + & NS & + & + \\
\hline Education monthly spending increased & + & NS & + & + & + & + \\
\hline
\end{tabular}

\section{INCOME}

\begin{tabular}{|l|c|c|c|c|c|c|}
\hline Monthly house disposable income increase & + & + & + & + & + & + \\
\hline Monthly work days lost to illness reduced & + & + & + & + & + & + \\
\hline
\end{tabular}

\section{HOUSING}

\begin{tabular}{|l|c|c|c|c|c|c|}
\hline No. of brick walled houses increased & + & + & + & + & + & + \\
\hline No. of tiled/stone floor houses increased & + & + & + & + & + & + \\
\hline No. of concrete roofed houses increased & + & NS & + & NS & + & + \\
\hline
\end{tabular}

\section{GENDER}

Gender related sanitation problem reduced

$\mathbf{N S}=$ Non-significant change or not possible to measure change

$+=$ Significant positive change and $-=$ Significant negative change 
Table 8 Robustness check through Wilcoxon test for the years of 1996 and 2006

\begin{tabular}{|c|c|c|c|c|}
\hline & \multicolumn{3}{|c|}{ Before and after for all settlements } & \multirow[b]{2}{*}{ Hansol } \\
\hline & Sanjaynagar & Ramdevnagar & Pravinnagar & \\
\hline \multicolumn{5}{|l|}{ WATER } \\
\hline Water supply pipes have increased & + & + & + & NS \\
\hline Maintenance for water supply reduced & + & + & + & NS \\
\hline
\end{tabular}

SEWERAGE

\begin{tabular}{|l|c|c|c|c|}
\hline Sewerage pipes have increased & + & + & + & NS \\
\hline Private/individual toilets has increased & + & + & + & NS \\
\hline
\end{tabular}

\section{ROADS}

Provision of roads has increased

\begin{tabular}{|c|c|c|c|}
\hline+ & + & + & NS \\
\hline
\end{tabular}

\section{STORM DRAINS}

\begin{tabular}{|l|c|c|c|c|}
\hline Storm drainage provisions has increased & + & + & + & NS \\
\hline Time loss due to rains has reduced & + & + & + & NS \\
\hline Money loss due to rains has reduced & + & + & + & NS \\
\hline
\end{tabular}

\section{ELECTRICITY}

Individual electricity connections increase

\begin{tabular}{|c|c|c|c|}
\hline+ & + & + & + \\
\hline
\end{tabular}

STREETLIGHTING

Street lighting provisions have increased

\begin{tabular}{|c|c|c|c|}
\hline+ & + & + & NS \\
\hline
\end{tabular}

\section{HEALTH}

Monthly house medical spending reduced

Per capita total disease rate has reduced

\begin{tabular}{|c|c|c|c|c|}
\hline$d$ & + & + & + & - \\
\hline & + & + & + & NS \\
\hline
\end{tabular}

\section{EDUCATION}

\begin{tabular}{|l|c|c|c|c|}
\hline Ability to Read/literacy increased & + & + & + & NS \\
\hline Male attendance has increased & + & NS & NS & NS \\
\hline Female attendance has increased & NS & NS & NS & NS \\
\hline Education monthly spending increased & NS & + & NS & NS \\
\hline
\end{tabular}

\section{INCOME}

\begin{tabular}{|l|c|c|c|c|}
\hline Monthly house disposable income increase & + & + & + & + \\
\hline Monthly work days lost to illness reduced & + & + & + & NS \\
\hline
\end{tabular}

\section{HOUSING}

\begin{tabular}{|l|c|c|c|c|}
\hline No. of brick walled houses increased & + & + & + & + \\
\hline No. of tiled/stone floor houses increased & + & + & + & + \\
\hline No. of concrete roofed houses increased & + & + & + & NS \\
\hline
\end{tabular}

\section{GENDER}

Gender related sanitation problem reduced

$\mathbf{N S}=$ Non-significant change or not possible to measure change

$+=$ Significant positive change and $-=$ Significant negative change 
Table 9 Descriptive statistics

\begin{tabular}{llllll}
\hline Indicator & Observation & Mean & Std. Dev. & Min & Max \\
\hline HEALTH COST & 474 & 7.65 & 6.19 & 0 & 79 \\
DISEASE & 474 & 1.75 & 0.86 & 0 & 6 \\
READ 5+ & 474 & 1.73 & 1.88 & 0 & 8 \\
MALE ATTEN & 474 & 0.61 & 0.82 & 0 & 4 \\
FEMALE ATTEN & 474 & 0.44 & 0.74 & 0 & 3 \\
DIS INCOME & 473 & 93 & 49 & 3 & 386 \\
HOUSE VALUE & 445 & 2171 & 2367 & 0 & 24245 \\
LAND VALUE & 426 & 2176 & 2736 & 44 & 44082 \\
SERVICE & 474 & 0.61 & 0.49 & 0 & 1 \\
FEMALE POP 22+ & 474 & 1.34 & 0.71 & 0 & 5 \\
FEMALE POP 5-22 & 474 & 1.40 & 1.26 & 0 & 7 \\
FAMILY SIZE & 474 & 6.1 & 2.5 & 1 & 24 \\
INFANT POP MALE & 474 & 0.37 & 0.67 & 0 & 4 \\
INFANT POP & & & & & \\
FEMALE & 474 & 0.29 & 0.59 & 0 & 3 \\
POP 5-20 & 474 & 1.75 & 1.93 & 0 & 9 \\
POP 22-36 & 474 & 1.09 & 1.26 & 0 & 7 \\
POP 37-52 & 474 & 0.60 & 0.84 & 0 & 7 \\
POP 53-68 & 474 & 0.17 & 0.45 & 0 & 2 \\
POP 69+ & 474 & 0.03 & 0.18 & 0 & 2 \\
INSTITUTION & 474 & 0.6 & 0.49 & 0 & 1 \\
DWELLING & 474 & 527 & 403 & 153 & 1200 \\
LAND OWNERSHIP & 474 & 0.61 & 0.49 & 0 & 1 \\
\hline
\end{tabular}


Table 10 Correlations between indicators

\begin{tabular}{|c|c|c|c|c|c|c|c|c|c|c|c|}
\hline & 1 & 2 & 3 & 4 & 5 & 6 & 7 & 8 & 9 & 10 & 11 \\
\hline 1 HEALTH COST & 1.00 & & & & & & & & & & \\
\hline 2 DISEASE & 0.12 & 1.00 & & & & & & & & & \\
\hline 3 READ 5+ & -0.11 & -0.30 & 1.00 & & & & & & & & \\
\hline 4 MALE ATTEN & -0.01 & -0.14 & 0.26 & 1.00 & & & & & & & \\
\hline 5 FEMALE ATTEN & -0.03 & -0.08 & 0.30 & 0.14 & 1.00 & & & & & & \\
\hline 6 DIS INCOME & 0.12 & -0.25 & 0.41 & 0.13 & 0.16 & 1.00 & & & & & \\
\hline 7 HOUSE VALUE & -0.08 & -0.26 & 0.44 & 0.09 & 0.11 & 0.31 & 1.00 & & & & \\
\hline 8 LAND VALUE & -0.07 & -0.24 & 0.32 & -0.01 & 0.05 & 0.22 & 0.35 & 1.00 & & & \\
\hline 10 FEMALE POP & 0.08 & -0.01 & 0.10 & 0.07 & 0.14 & 0.27 & 0.21 & 0.07 & 0.16 & 1.00 & \\
\hline 11 FEMALE POP 5-22 & 0.10 & 0.07 & 0.13 & 0.02 & 0.47 & 0.12 & -0.05 & 0.03 & -0.07 & -0.03 & 1.00 \\
\hline 12 FAMILY SIZE & 0.19 & 0.08 & 0.07 & 0.23 & 0.25 & 0.28 & -0.02 & -0.01 & -0.01 & 0.51 & 0.57 \\
\hline 13 INFANT POP MALE & 0.04 & 0.10 & -0.10 & -0.09 & -0.01 & 0.07 & -0.08 & -0.05 & -0.04 & 0.12 & 0.08 \\
\hline 14 INFANT POP FEMALE & 0.13 & 0.11 & -0.15 & -0.10 & 0.01 & -0.02 & -0.09 & -0.09 & -0.10 & 0.13 & -0.04 \\
\hline 15 POP 5-20 & 0.17 & 0.26 & -0.27 & 0.18 & 0.13 & -0.08 & -0.38 & -0.23 & -0.41 & 0.00 & 0.54 \\
\hline 16 POP $22-36$ & 0.12 & 0.21 & -0.37 & -0.08 & -0.03 & -0.05 & -0.32 & -0.21 & -0.26 & 0.36 & 0.11 \\
\hline 17 POP $37-52$ & 0.12 & 0.07 & -0.17 & 0.01 & 0.05 & 0.07 & -0.22 & -0.14 & -0.22 & 0.11 & 0.25 \\
\hline 18 POP 53-68 & 0.01 & 0.14 & -0.12 & 0.00 & 0.01 & -0.03 & -0.10 & -0.08 & -0.11 & 0.32 & -0.04 \\
\hline 20 INSTITUTION & -0.03 & -0.03 & 0.43 & 0.09 & 0.17 & 0.16 & 0.32 & 0.26 & 0.11 & 0.16 & -0.08 \\
\hline 21 DWELLING & -0.09 & -0.37 & 0.56 & 0.05 & 0.05 & 0.28 & 0.48 & 0.42 & 0.59 & 0.09 & -0.10 \\
\hline \multirow[t]{2}{*}{22 LAND OWNERSHIP } & -0.03 & -0.14 & -0.12 & 0.01 & -0.02 & 0.01 & 0.02 & -0.16 & 0.23 & -0.07 & 0.01 \\
\hline & 12 & 13 & 14 & 15 & 16 & 17 & 18 & 19 & 20 & 21 & 22 \\
\hline 12 FAMILY SIZE & 1.00 & & & & & & & & & & \\
\hline 13 INFANT POP MALE & 0.42 & 1.00 & & & & & & & & & \\
\hline 14 INFANT POP FEMALE & 0.30 & 0.11 & 1.00 & & & & & & & & \\
\hline 15 POP 5-20 & 0.53 & 0.00 & 0.09 & 1.00 & & & & & & & \\
\hline 16 POP $22-36$ & 0.48 & 0.31 & 0.31 & 0.38 & 1.00 & & & & & & \\
\hline 17 POP $37-52$ & 0.34 & 0.02 & 0.01 & 0.52 & 0.23 & 1.00 & & & & & \\
\hline 18 POP 53-68 & 0.18 & -0.01 & 0.06 & 0.13 & 0.34 & -0.05 & 1.00 & & & & \\
\hline 19 POP $69+$ & 0.15 & -0.01 & 0.01 & 0.11 & 0.14 & 0.03 & 0.06 & 1.00 & & & \\
\hline 20 INSTITUTION & -0.10 & -0.13 & -0.17 & -0.39 & -0.35 & -0.25 & -0.07 & -0.05 & 1.00 & & \\
\hline 21 DWELLING & -0.14 & -0.10 & -0.16 & -0.55 & -0.48 & -0.37 & -0.18 & -0.11 & 0.32 & 1.00 & \\
\hline 22 LAND OWNERSHIP & -0.01 & 0.03 & 0.05 & 0.00 & -0.02 & -0.05 & -0.09 & -0.01 & 0.43 & -0.26 & 1.00 \\
\hline
\end{tabular}

Number of observations: 405 
Table 11 Regression results

\begin{tabular}{|c|c|c|c|c|c|c|c|c|c|c|c|c|}
\hline INDICATORS & Model 1a & $\begin{array}{l}\text { Model 1b } \\
\text { ALTH C }\end{array}$ & $\begin{array}{l}\text { Model 1c } \\
\mathbf{T}\end{array}$ & Model 2a & $\begin{array}{c}\text { Model 2b } \\
\text { DISEASE }\end{array}$ & Model 2c & Model 3a & $\begin{array}{l}\text { Model 3b } \\
\text { READ 5+ }\end{array}$ & Model 3c & Model 4a & $\begin{array}{l}\text { Model 4b } \\
\text { LE ATTE }\end{array}$ & Mode 4c \\
\hline \multicolumn{13}{|l|}{ Independent } \\
\hline \multirow[t]{2}{*}{ SERVICE } & & $-0.32 *$ & $-0.35^{* *}$ & & $-1.02 * * *$ & $-1.07 * * *$ & & $0.57 * * *$ & $0.59 * * *$ & & $0.61 * * *$ & $0.60^{* * *}$ \\
\hline & & $(0.131)$ & $(0.133)$ & & $(0.111)$ & $(0.112)$ & & $(0.109)$ & $(0.111)$ & & $(0.119)$ & $(0.121)$ \\
\hline \multirow[t]{2}{*}{ FEMALE POP 22+ } & & -0.00 & 0.11 & & $0.10+$ & $0.25 * *$ & & -0.09 & -0.13 & & $-0.27 * * *$ & $-0.23 *$ \\
\hline & & $(0.068)$ & $(0.105)$ & & $(0.057)$ & $(0.089)$ & & $(0.056)$ & $(0.088)$ & & $(0.061)$ & $(0.095)$ \\
\hline \multirow[t]{2}{*}{ FEMALE POP 5-22 } & & -0.04 & 0.03 & & 0.06 & 0.08 & & 0.08 & 0.07 & & $-0.52 * * *$ & $-0.45 * * *$ \\
\hline & & $(0.066)$ & $(0.077)$ & & $(0.056)$ & $(0.065)$ & & $(0.055)$ & $(0.065)$ & & $(0.060)$ & $(0.070)$ \\
\hline SERVICE X FEMALE POP 22+ & & & $-0.17+$ & & & $-0.19 *$ & & & 0.06 & & & -0.09 \\
\hline \multirow{2}{*}{ SERVICE X FEMALE POP 5-22 } & & & $(0.099)$ & & & $(0.084)$ & & & $(0.082)$ & & & $(0.090)$ \\
\hline & & & $\begin{array}{l}-0.15+ \\
(0.092)\end{array}$ & & & $\begin{array}{c}-0.03 \\
(0.078)\end{array}$ & & & $\begin{array}{c}0.03 \\
(0.077)\end{array}$ & & & $\begin{array}{c}-0.15+ \\
(0.084)\end{array}$ \\
\hline \multicolumn{13}{|l|}{ Control: household level } \\
\hline \multirow[t]{2}{*}{ FAMILY SIZE } & 0.11 & 0.17 & $0.18+$ & -0.09 & -0.07 & -0.10 & $0.41 * * *$ & $0.34 * * *$ & $0.34 * * *$ & $0.42 * * *$ & $0.85^{* * *}$ & $0.88 * * *$ \\
\hline & $(0.082)$ & $(0.107)$ & $(0.110)$ & $(0.076)$ & $(0.091)$ & $(0.093)$ & $(0.070)$ & $(0.089)$ & $(0.092)$ & $(0.083)$ & $(0.097)$ & $(0.100)$ \\
\hline \multirow[t]{2}{*}{ INFANT POP MALE } & -0.02 & -0.05 & -0.05 & $0.12 *$ & $0.09+$ & $0.10^{*}$ & $-0.15^{* *}$ & $-0.13 * *$ & $-0.13 * *$ & $-0.19 * * *$ & $-0.28 * * *$ & $-0.29 * * *$ \\
\hline & $(0.055)$ & $(0.058)$ & $(0.058)$ & $(0.051)$ & $(0.049)$ & $(0.049)$ & $(0.047)$ & $(0.048)$ & $(0.048)$ & $(0.056)$ & $(0.053)$ & $(0.052)$ \\
\hline \multirow[t]{2}{*}{ INFANT POP FEMALE } & 0.08 & 0.06 & 0.05 & 0.07 & 0.05 & 0.05 & $-0.10^{*}$ & -0.07 & -0.07 & $-0.15 * *$ & $-0.24 * * *$ & $-0.25 * * *$ \\
\hline & $(0.049)$ & $(0.051)$ & $(0.051)$ & $(0.045)$ & $(0.043)$ & $(0.043)$ & $(0.042)$ & $(0.042)$ & $(0.042)$ & $(0.049)$ & $(0.046)$ & $(0.046)$ \\
\hline \multirow[t]{2}{*}{ POP 5-20 } & 0.07 & 0.04 & 0.00 & $0.18^{*}$ & 0.08 & 0.07 & $-0.15^{*}$ & $-0.14 *$ & $-0.14+$ & 0.11 & $0.25^{* *}$ & $0.21 * *$ \\
\hline & $(0.082)$ & $(0.087)$ & (0.089) & $(0.076)$ & $(0.074)$ & $(0.076)$ & $(0.070)$ & $(0.072)$ & $(0.075)$ & $(0.083)$ & $(0.079)$ & $(0.081)$ \\
\hline \multirow[t]{2}{*}{ POP 22-36 } & 0.03 & 0.03 & 0.01 & -0.03 & -0.02 & -0.04 & $-0.19 * * *$ & $-0.17 * *$ & $-0.16^{* *}$ & $-0.16^{*}$ & $-0.18 * *$ & $-0.19 * *$ \\
\hline & $(0.065)$ & $(0.068)$ & $(0.068)$ & $(0.060)$ & $(0.057)$ & (0.058) & $(0.056)$ & $(0.056)$ & $(0.057)$ & $(0.066)$ & $(0.062)$ & $(0.062)$ \\
\hline \multirow[t]{2}{*}{ POP $37-52$} & 0.04 & 0.04 & 0.02 & $-0.11 *$ & $-0.09+$ & $-0.10^{*}$ & -0.01 & -0.00 & 0.00 & $-0.13^{*}$ & $-0.17 * * *$ & $-0.19 * * *$ \\
\hline & $(0.055)$ & $(0.056)$ & $(0.056)$ & $(0.051)$ & $(0.047)$ & $(0.048)$ & $(0.047)$ & $(0.047)$ & $(0.047)$ & $(0.056)$ & $(0.051)$ & $(0.051)$ \\
\hline \multirow[t]{2}{*}{ POP 53-68 } & -0.03 & -0.03 & -0.04 & 0.05 & 0.05 & 0.03 & -0.02 & 0.00 & 0.01 & -0.03 & -0.04 & -0.04 \\
\hline & $(0.049)$ & $(0.051)$ & $(0.051)$ & $(0.046)$ & $(0.043)$ & $(0.043)$ & $(0.042)$ & $(0.042)$ & $(0.043)$ & $(0.050)$ & $(0.046)$ & $(0.046)$ \\
\hline \multirow[t]{2}{*}{ POP $69+$} & -0.02 & -0.03 & -0.05 & -0.03 & -0.05 & $-0.06+$ & -0.01 & 0.01 & 0.02 & 0.01 & 0.01 & 0.00 \\
\hline & $(0.043)$ & $(0.043)$ & $(0.043)$ & $(0.040)$ & $(0.037)$ & $(0.037)$ & $(0.037)$ & $(0.036)$ & $(0.036)$ & $(0.044)$ & $(0.039)$ & $(0.039)$ \\
\hline \multicolumn{13}{|l|}{ Control: slum level } \\
\hline \multirow[t]{2}{*}{ INSTITUTION } & 0.12 & 0.10 & -0.01 & 0.26 & 0.17 & 0.09 & $0.41 * *$ & $0.49 * * *$ & $0.52 * * *$ & 0.18 & $0.29+$ & 0.21 \\
\hline & $(0.173)$ & $(0.176)$ & $(0.180)$ & $(0.160)$ & $(0.149)$ & $(0.153)$ & $(0.148)$ & $(0.146)$ & $(0.151)$ & $(0.175)$ & $(0.159)$ & $(0.164)$ \\
\hline \multirow[t]{2}{*}{ DWELLING } & -0.03 & 0.07 & 0.05 & $-0.39 * * *$ & -0.09 & -0.09 & $0.32 * * *$ & $0.15^{*}$ & $0.15^{*}$ & -0.04 & $-0.20 * *$ & $-0.22 * *$ \\
\hline & $(0.070)$ & $(0.080)$ & $(0.081)$ & $(0.065)$ & $(0.068)$ & $(0.069)$ & $(0.060)$ & $(0.067)$ & $(0.068)$ & $(0.070)$ & $(0.073)$ & $(0.074)$ \\
\hline LAND OWNERSHIP & 0.00 & 0.12 & 0.08 & $-0.33^{*}$ & 0.03 & 0.02 & 0.20 & 0.02 & 0.03 & 0.13 & -0.04 & -0.09 \\
\hline & $(0.150)$ & $(0.159)$ & $(0.160)$ & $(0.140)$ & $(0.135)$ & $(0.136)$ & $(0.129)$ & $(0.132)$ & $(0.134)$ & $(0.152)$ & $(0.145)$ & $(0.146)$ \\
\hline Constant & -0.08 & 0.06 & 0.18 & 0.00 & $0.47 * *$ & $0.57 * *$ & $-0.35^{*}$ & $-0.65 * * *$ & $-0.69 * * *$ & -0.20 & $-0.54 * *$ & $-0.46^{*}$ \\
\hline & $(0.189)$ & $(0.199)$ & $(0.205)$ & $(0.176)$ & $(0.169)$ & $(0.174)$ & $(0.162)$ & $(0.166)$ & $(0.171)$ & (0.192) & $(0.181)$ & $(0.186)$ \\
\hline & -0.08 & 0.06 & 0.18 & 0.00 & $0.47 * *$ & $0.57 * *$ & $-0.35^{*}$ & $-0.65 * * *$ & $-0.69 * * *$ & -0.20 & $-0.54 * *$ & $-0.46^{*}$ \\
\hline Observations & 405 & 405 & 405 & 405 & 405 & 405 & 405 & 405 & 405 & 405 & 405 & 405 \\
\hline R-squared & 0.05 & 0.07 & 0.08 & 0.23 & 0.37 & 0.38 & 0.43 & 0.47 & 0.47 & 0.17 & 0.35 & 0.35 \\
\hline
\end{tabular}




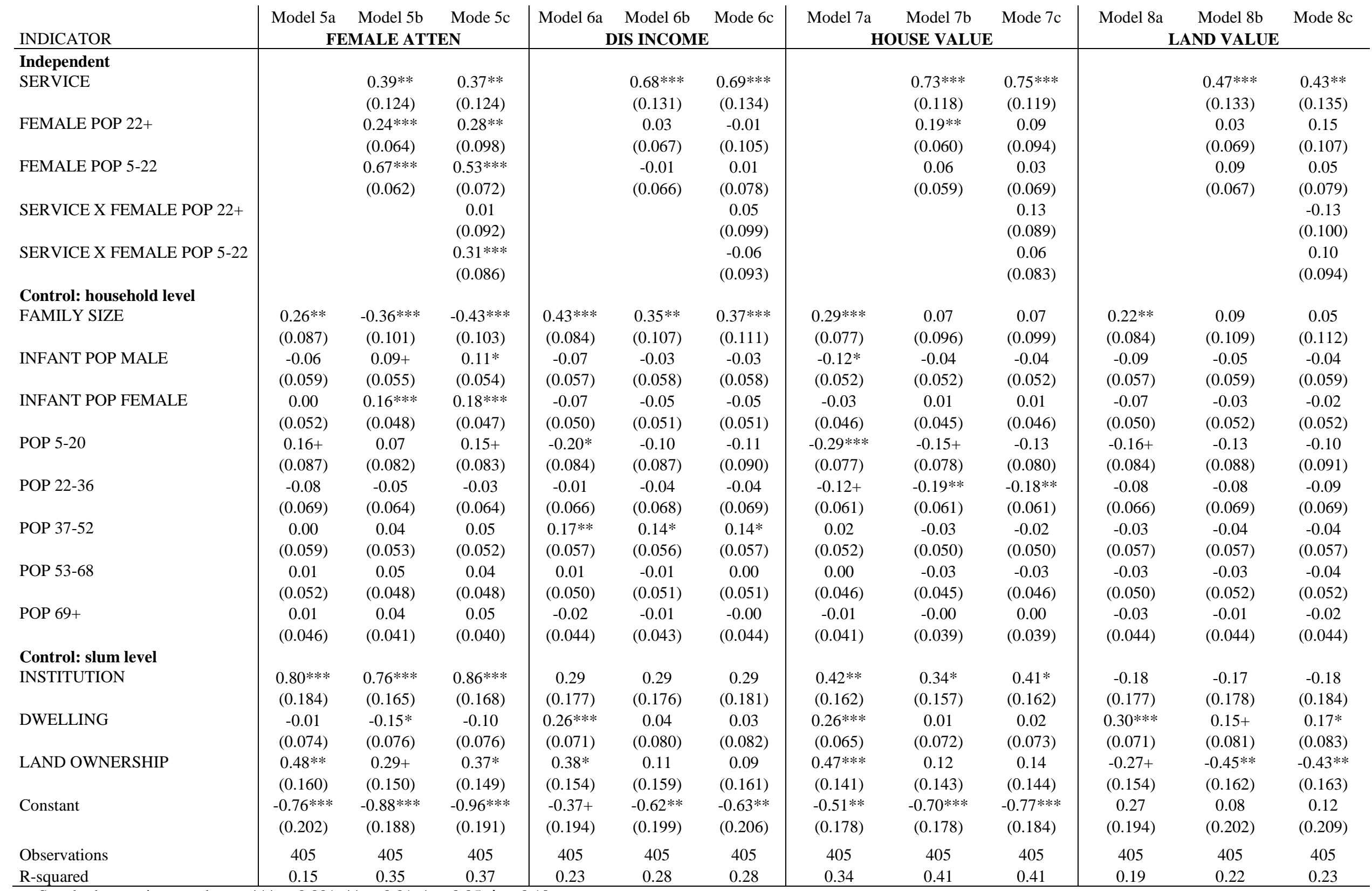

Standard errors in parentheses. $* * * \mathrm{p}<0.001,{ }^{* *} \mathrm{p}<0.01, * \mathrm{p}<0.05, \dagger \mathrm{p}<0.10$. 
Figure 1 Household per capita disease rate

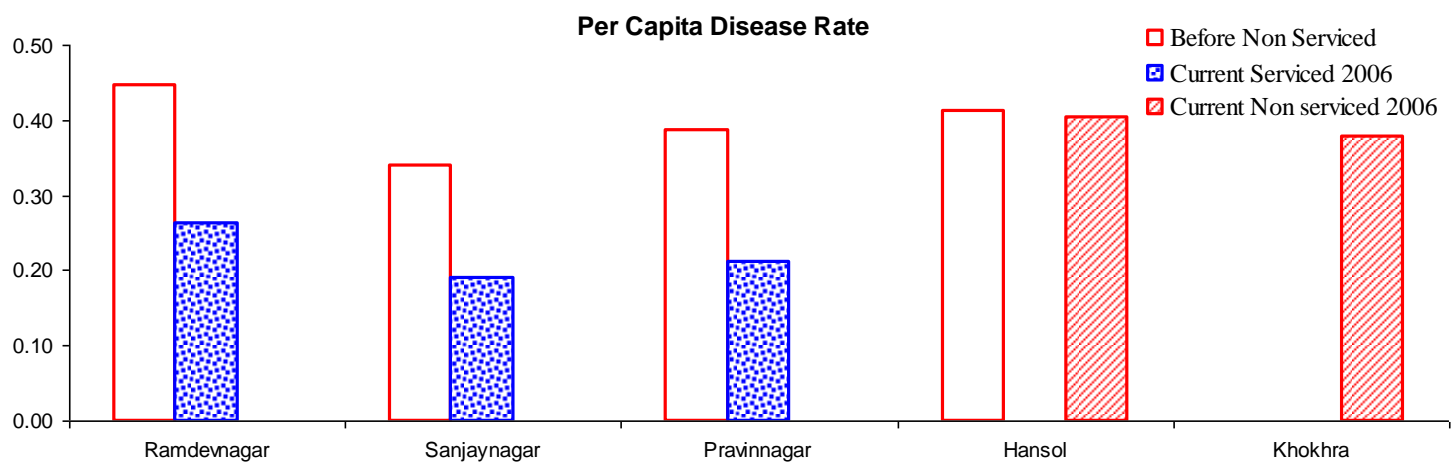


Figure 2 Monthly household work days lost due to illness

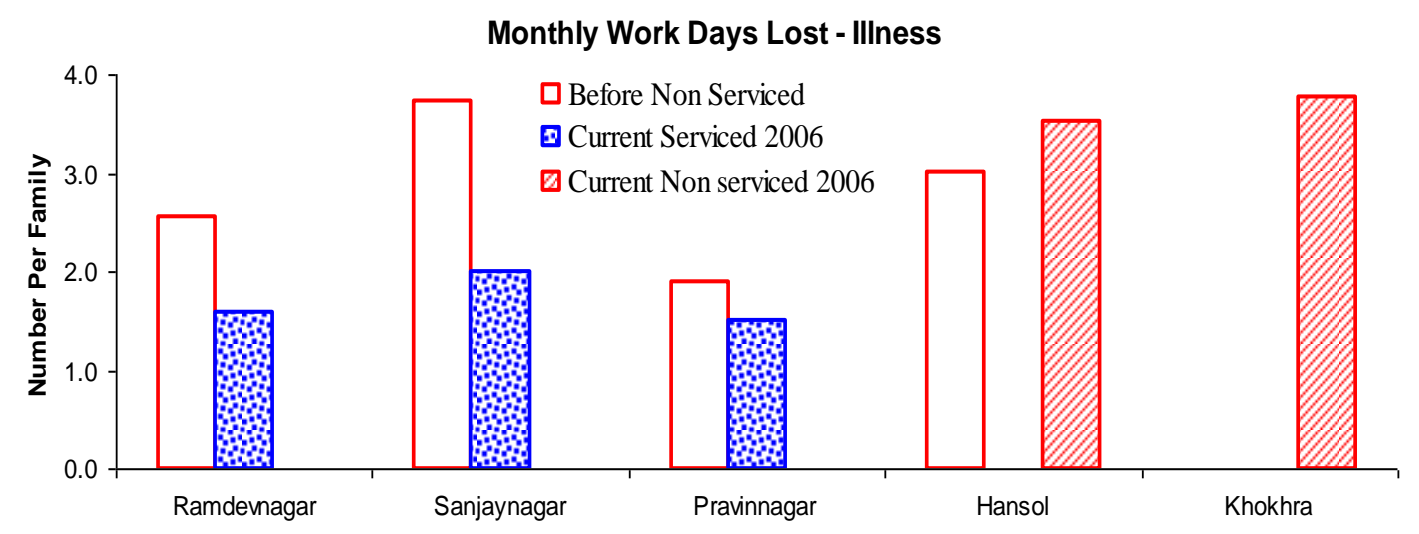

Figure 3 Time loss due to rains

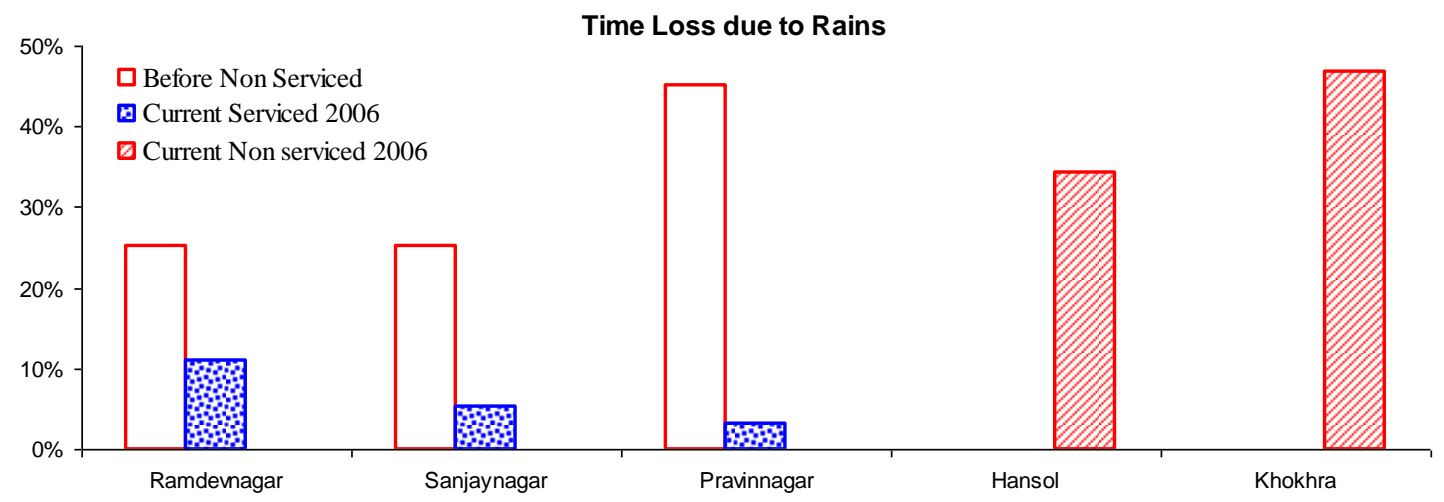


Figure 4 Gender related sanitation problems

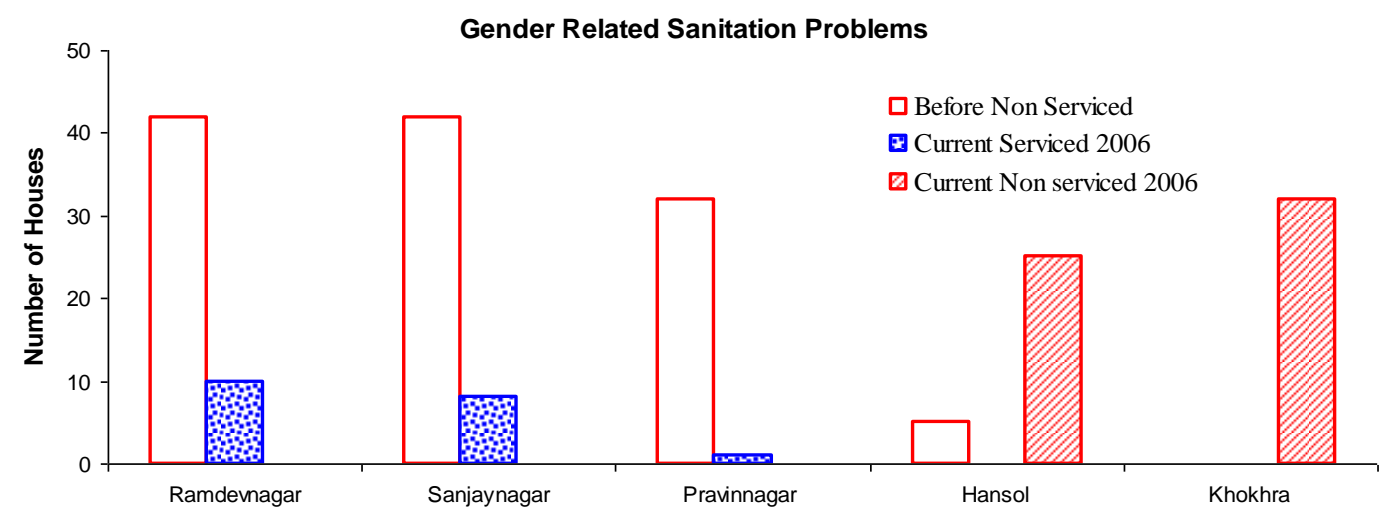

Figure 5 Problems associated with public toilets

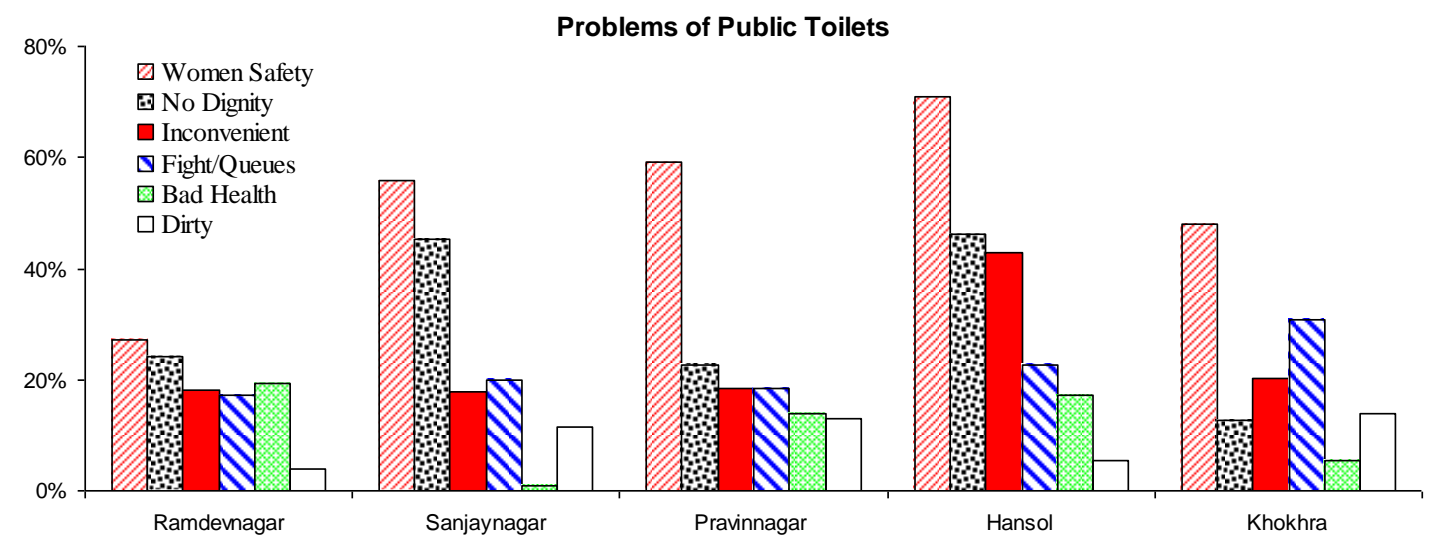


Figure 6 Benefits of individual water connections

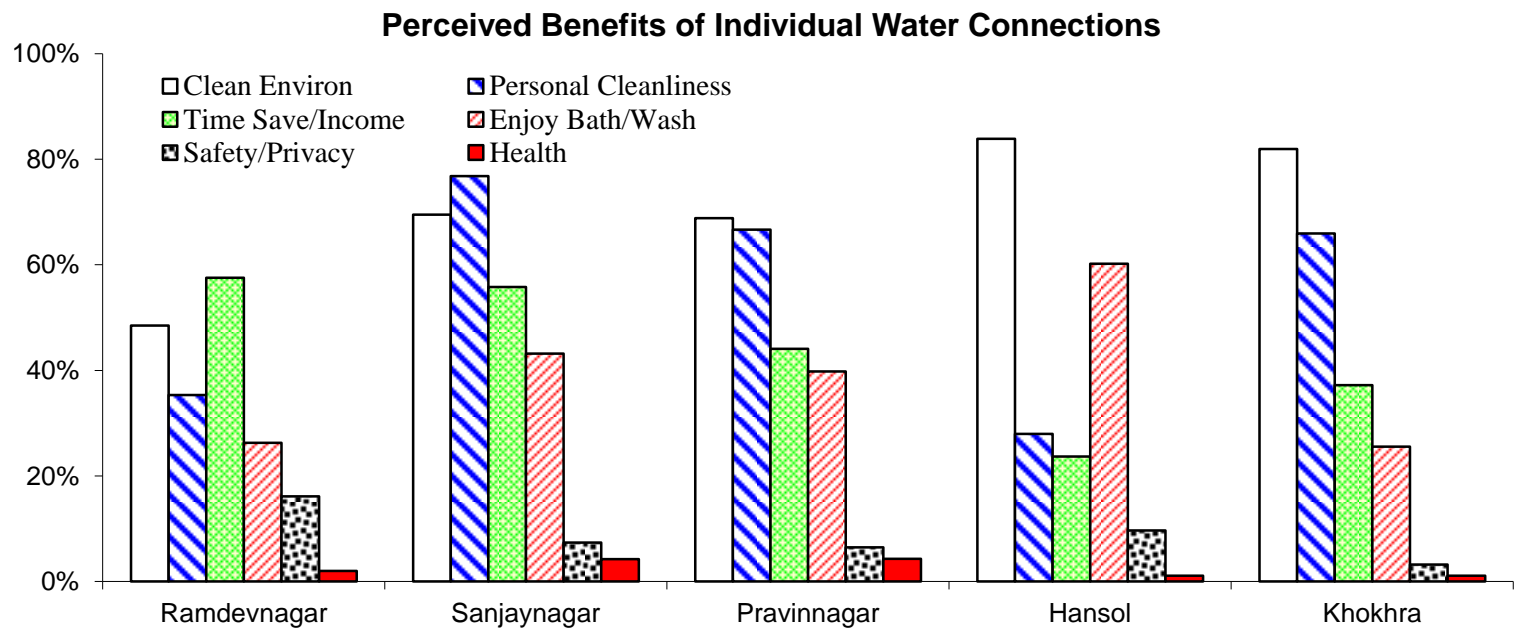

Figure 7 Who spends time for water collection and disposal
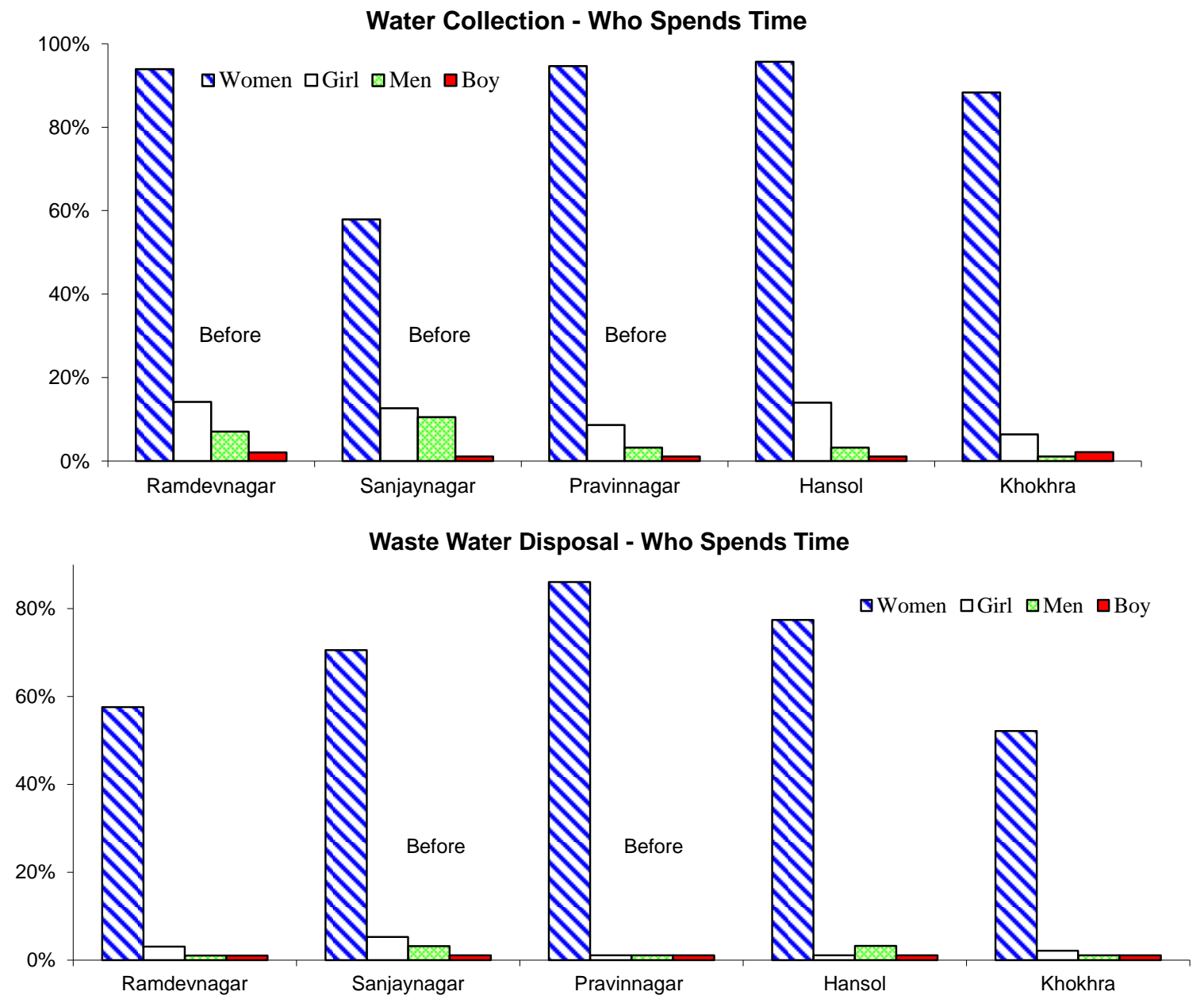
Figure 8 Moderation Effect of Female Population (22+) on Household's Health Cost and Disease Incidence
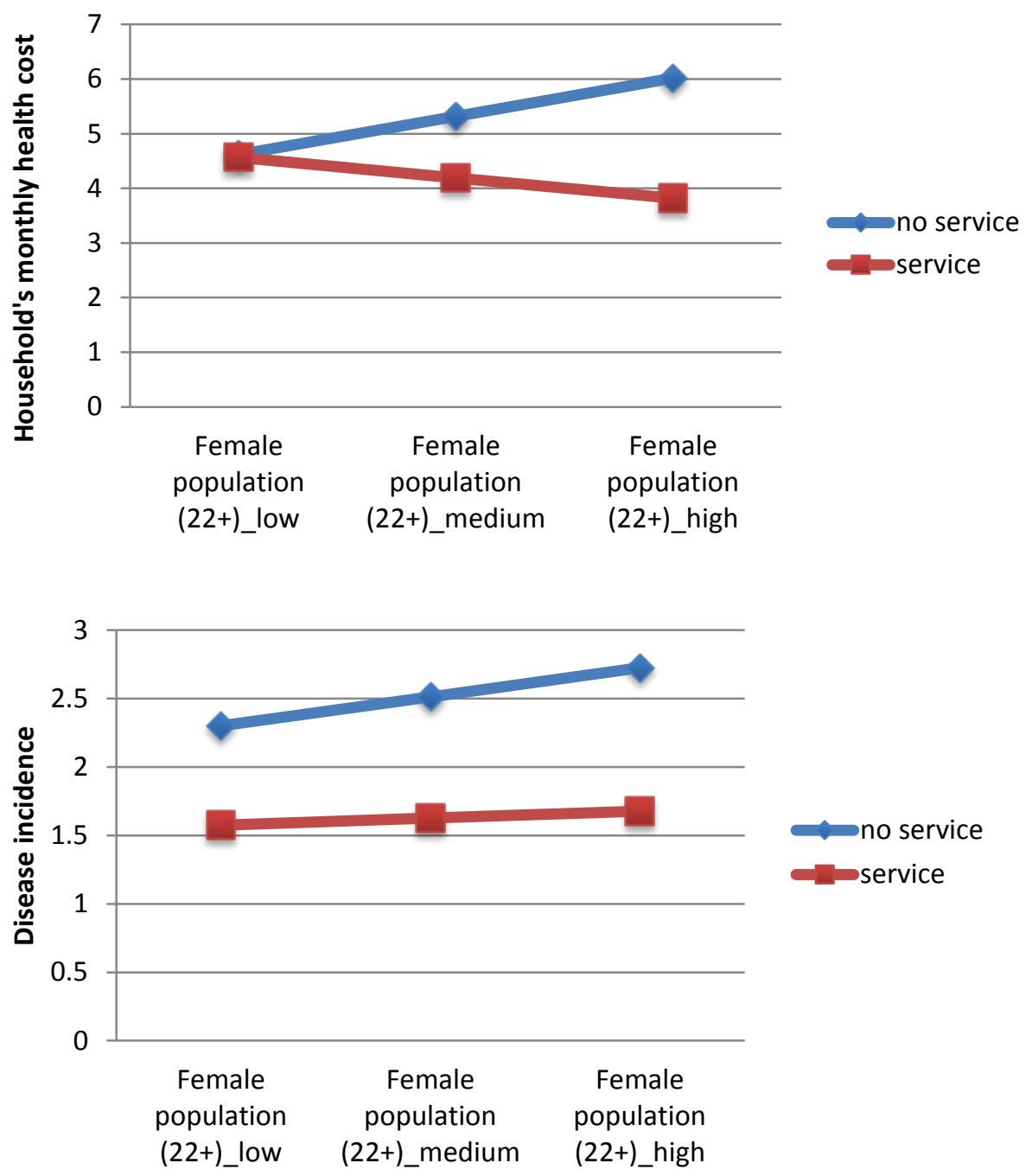

Figure 9 Moderation Effect of Female Population (5-22) on Female School Attendance

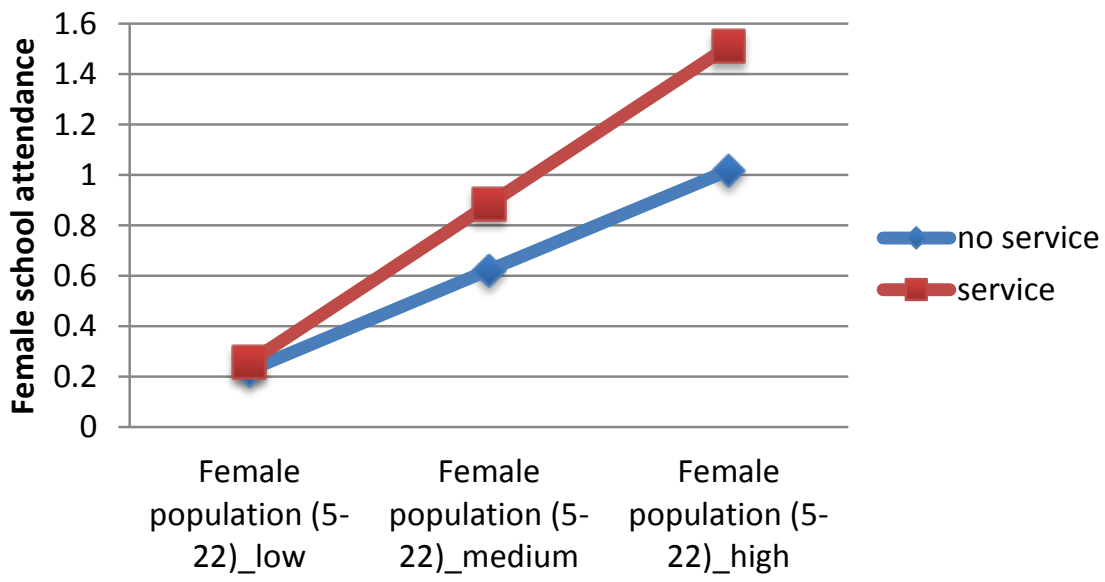

